\title{
Research Paper \\ Designing and editing an empowerment education package (with self- determination approach) and its effectiveness on student math performance and beliefs (with low performance in this lesson)
}

\begin{abstract}
Citation: Malekzadeh Sh, Hejazi E, Kiamanesh A. designing and editing an empowerment education package (with self- determination approach) and its effectiveness on student math performance and beliefs (with low performance in this lesson). $\mathrm{J}$ of Psychological Science. 2021; 20(103): 1095-1115.
\end{abstract}

Shima Malekzadeh ${ }^{1}$, Elahe Hejazi ${ }^{2}$, Alireza Kiamanesh ${ }^{3}$

1. Ph.D Student in Educational Psychology, Department of Psychology, Faculty of Psychology and Educational Sciences, Islamic Azad University, Science and Research Branch, Tehran, Iran.

2. Associate Professor, Department of Psychology and Consulting, Faculty of Psychology and Educational Sciences, Tehran University, Tehran, Iran.

3. Professor, Department of Psychology, Faculty of Psychology and Educational Sciences, Kharazmi University, Tehran,Iran.
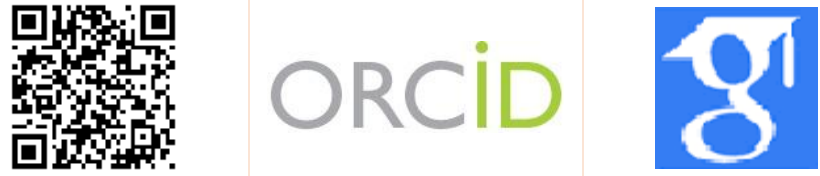

$\underline{10.52547 / J P S .20 .103 .1095}$
URL: https://psychologicalscience.ir/article-1-1102-fa.html

\section{A R T I C L E I N F O}

Keywords:

empowerment education package,

self- determination, educational performance, math beliefs, girl and boy student

Received: 03 Jan 2021 Accepted: 29 Jan 2021 Available: 23 Sep 2021

\section{A B S T R A C T}

Background: Numerous studies have examined the effect of self - determination education on student learning, but research that has developed designing and editing an empowerment education package with self- determination approach and its effectiveness on student math performance and belifs has been neglected.

Aims: the purpose of this was to designing and editing an empowerment education package with self- determination approach and its effectiveness on girl and boy students math performance and belifs with low performance in this lesson.

Methods: The present study was applied in terms of purpose and combined in terms of method(qualitative and quantitative), the qualitative part was the design of a education package and the quantitative part was semi-experimental with design pre-test,post-test and follow with control group. The study population consisted of all students ninth grade in 6 district Tehran city during the years 2019-2020 with low performance in math. 32 people were targeted selected as a sample and randomly assigned to two experimental and control groups (16 people). The instruments of the present study were Leder and Forgasz (2002) mathematical Academic Belief Questionnaire, For the experimental group, training was held in 8 sessions of 60 minutes While the control group did not receive any intervention. Proposed research package for empowerment education with selfdetermination approach it was designed based on the theory of Deci \& Ryan (2004). Data analysis was performed by frequent measurments analysis of variance.

Results: an empowerment education package with self-determination approach had a significant effect on math performance and belifs (with low performance in this lesson) $(\mathrm{P}<0 / 01)$.

Conclusion: girl and boy students who participated in empowerment education sessions based on self-determination approach had better performance and Improvement beliefs to math lesson. Therefore, it is recommended to be considered as one of the educational programs at educational institutions Including Ministry of Education.

* Corresponding Author: Elahe Hejazi, Associate Professor, Department of Psychology and Consulting, Faculty of Psychology and Educational Sciences, Tehran University, Tehran, Iran.

E-mail: ehejazi@ut.ac.ir

Tel: (+98) 9126025699

2476-5740/ (C) 2021 The Authors. This is an open access article under the CC BY-NC-ND license

(https://creativecommons.org/licenses/by-nc/4.0/). 


\section{Extended Abstract}

\section{Introduction}

The development of societies depends on organized knowledge obtained through research and mathematics is the basis of many of these research findings; Therefore, the level of application of mathematical knowledge in societies can be one of the criteria for development (Jalili, Arefi, Qamrani and Manshei, 2019). Today, education systems around the world are struggling help develop learners' mental abilities and the power of logical reasoning by incorporating math topics into their curriculum and help them keep abreast of scientific developments and advances in technology and future life(Rastegar, Ghorban Jahromi, Gholam Ali Lavasani and Nikbakht, 2015). One of the goals of math lessons is to create learners' mental abilities and mental order and the purpose of its teaching is to develop the power of comprehension, understanding, But there are obstacles to teaching math that not only make teaching this subject difficult,reasoning, to cultivate rational thinking, and to develop a method of reasoning, logical thinking, and creativity; Rather, it has overshadowed the lives of different people by creating a mathematical decline(Bayban Guard, 2010, quoted by Ebrahim Kafouri, Maleki and Khosrow Babadi, 2014). Alizadeh Gorji (2010), mentions several reasons for math failure, including Including lack of self-confidence and recognition of learners' weaknesses; the difficulty of mathematics from the point of view of learners; one's attitude towards learning mathematics and the learner's lack of understanding and connection with mathematics.

Various researches on mathematical academic performance have been done from different aspects. one of the factors that has received special attention is the beliefs that students have about the nature of mathematics and its assignments. Attitudes and beliefs play a major role in all matters of life and affect relationships and in matters related to education and learning and courses such as mathematics are no exception while not only is mathematical talent a myth, there is no such thing as a mathematical brain but this belief continues to be widely and deeply promoted in society (Boller, Williams, \& Manson,
2018). Someone who believes he can be successful in math, will really perform optimally in math lessons. Beliefs are motivational factors that can lead people to goals (Pishgahi Fard, Zohdi Goharpour and Abedini Rad, 2014).

As mentioned, beliefs play an important role in performance. Various teaching methods have been used to improve students' mathematical academic performance, one of the methods that is used recently is the training of cognitive empowerment skills (Zaraati Idealo, Zargham Hajebi and Kamkari, 2020). In this research, more emphasis is placed on psychological empowerment. Spritzer (1995-1996) considers psychological empowerment as an internal motivational concept consisting of five dimensions Competence is defined as autonomy (right to choose), meaningfulness, influence and trust (Ghasemi, Alizadeh and Kandahari, 2018). Spritzer (1995) has introduced one of the dimensions of empowerment as self-determination (Charmchian Langroudi and Ali Beigi, 2017).

By examining the research background, none of these studies have examined the effectiveness of the empowerment training package with a selfdetermining approach on the performance and mathematical beliefs of male and female students. Therefore, presenting an empowerment package with a self-determination approach and evaluating its effectiveness on students' performance and mathematical beliefs seems necessary. Therefore, the present study intends to develop an empowerment training package with a self-determination approach, Examine the question of whether is this program effective in the performance and math beliefs of ninth grade male and female students who are performing poorly in this course?

\section{Method}

The present study was applied in terms of purpose and in terms of method of Combined type (qualitative and quantitative) includes a qualitative part of the formulation and design of empowerment training package with a self-determination approach and a small part of the quasi-experimental type with pretest-post-test design and follow-up with the control group. First stage: in the first phase, based on the available theoretical evidence, the researcher 


\section{Monthly Journal of Psychological Science}

Vol. 20, No. 103, Autumn(October) 2021

developed a complete version of the empowerment training package with a self-determination approach. after compiling the initial version of the empowerment training package, in order to determine the face and content validity, it was provided to several experts for evaluation. After collecting the evaluative opinions of experts and carefully applying the suggestions, the correction was closed for final implementation.

In the second phase of research the effectiveness of the empowerment training package with selfdetermination approach was tested on ninth grade male and female students using a pre-test-post-test and follow-up with a quasi-experimental design. The statistical population of the present study is all ninth grade male and female students in the first year of high school District 6 of Tehran Education has formed the 98-99 academic year, which has a low performance in mathematics. To determine the sample group in this study, among the schools in District 6 of Tehran, four schools were selected by random sampling. Then, from the selected schools, 32 ninth grade male and female students with low performance in mathematics were selected by purposive sampling.

Mathematical Academic Beliefs Questionnaire: This scale was developed by Leder and Forges in 2002 contains 31 questions or items that aim to examine the component of students' mathematical academic beliefs and individually based on a 5-point Likert scale. Validity and reliability of this questionnaire abroad by Loader and Forges (2002) and has been studied in Iran by Faramarzpour, Rafipour and Hossein Chari (2015). In the research of Faramarzpour, Rafipour and Hossein Chari (2015) the value of Cronbach's alpha coefficient is 0.815 and Bartlett spherical test coefficient is equal to $1502 / 14$ which is significant at the level of 0.0001 the calculated reliability for the pre-test of mathematical academic beliefs without gender segregation was 0.38 . Collect the required data and the findings were analyzed using SPSS software version 26 and repeated measures analysis of variance to measure effectiveness.

Table 1. Results of Mohli sphericity test for homogeneity of variance

\begin{tabular}{ccccccc}
\hline Internal impact & Mocheli test & Chi-square test & Df & Sig & Greenhouse-Geisser & Lower-bound \\
\hline Mathematical performance & $0 / 89$ & $2 / 938$ & 2 & $0 / 23$ & $0 / 90$ & $0 / 50$ \\
Mathematical beliefs & $0 / 19$ & $44 / 199$ & 2 & $0 / 001$ & $0 / 55$ & $0 / 50$ \\
\hline
\end{tabular}

\section{Results}

To test research hypotheses, the research first examined the correlation between the pre-test variables of mathematical academic beliefs and mathematical performance. First, its presuppositions are: the continuity of the dependent variable, the normality of the data distribution, the homogeneity of the covariances of the two groups, and the independence of the individuals were examined. To investigate the natural distribution of data from the Shapiro-Wilk test and the Mochley test was used to test the assumption that the variance was uniform. Levin test was used to evaluate the homogeneity of variance of performance scores and mathematical academic belief in the two groups in the post-test and follow-up stages. The results of Shapirovilk test showed that the obtained data have a normal distribution. To assume linearity, correlation coefficients between variables were used and the correlation coefficients between pre-test and post-test were $r=0.44$. Levin test was used to test the assumption of homogeneity of error variances. Based on the results, the significance level for the performance variable is sig $=0.10$ and for the mathematical beliefs variable is sig $=0.25$ greater than 0.05 . Therefore, the assumption of homogeneity of error variances is established. Also, Mbox test was performed to examine the variance matrices in two groups with a significance level greater than 0.01 . Because these assumptions were true in the data, repeated measures analysis of variance was used.

To analyze the variance of a factor with emphasis on intra-subject study (repeated measurements). The output of this test is presented in Table 1. Considering that the significance level of the calculated value of the spherical sphericity for the mathematical performance variable is greater than 0.05 , the data did not call into question the assumption of homogeneity of variance and as for the mathematical beliefs variable, considering that the significance level of the 


\section{Monthly Journal of Psychological Science}

calculated value of the spherical sphericity is less than 0.05 , the data question the assumption of homogeneity of variance therefore, epsilon estimation or multivariate tests should be used to correct the hypothesis breach. Considering the appropriate sample size of this study, the best amount of epsilon is Greenhouse-Geiser estimate.

Table 2 summarizes the analysis of variance of mathematical performance scores. Summary of intragroup analysis of variance indicates that the interactive effect between mathematical performance and the group is significant. This interaction indicates that different results have been obtained by combining the levels of mathematical performance (pre-test, post-test and follow-up) and the operating

Table 2. Results of intragroup and intergroup analysis of variance (mathematical performance)

\begin{tabular}{|c|c|c|c|c|c|c|}
\hline & Variable sources & SS & Df & Ms & $\mathrm{F}$ & Sig \\
\hline \multirow{5}{*}{ Intergroup } & Math Performance & $202 / 79$ & 2 & $101 / 395$ & $82 / 162$ & $0 / 001$ \\
\hline & $\begin{array}{c}\text { Math Performance * } \\
\text { Gender }\end{array}$ & $4 / 03$ & 2 & $2 / 01$ & $1 / 63$ & $0 / 20$ \\
\hline & $\begin{array}{l}\text { Math Performance * } \\
\text { Group }\end{array}$ & $13 / 13$ & 2 & $65 / 56$ & $53 / 13$ & $0 / 001$ \\
\hline & $\begin{array}{l}\text { Math Performance * } \\
\text { Gender * Group }\end{array}$ & $0 / 30$ & 2 & $0 / 15$ & $0 / 12$ & $0 / 88$ \\
\hline & Error & $69 / 10$ & 56 & $1 / 23$ & & \\
\hline \multirow{4}{*}{ Betweengroup } & Gender & $40 / 69$ & 1 & $40 / 69$ & $2 / 70$ & $0 / 11$ \\
\hline & Group & $176 / 04$ & 1 & $176 / 04$ & $11 / 68$ & $0 / 002$ \\
\hline & Gender * Group & $37 / 50$ & 1 & $37 / 50$ & $2 / 49$ & $0 / 11$ \\
\hline & Error & $421 / 70$ & 28 & $15 / 06$ & & \\
\hline
\end{tabular}

Table 3 summarizes the analysis of variance of mathematical belief scores. Summary of intragroup analysis of variance indicates that the interaction effect between mathematical academic beliefs and the group is significant. This interaction indicates that different results have been obtained by combining the levels of mathematical beliefs (pre-test, post-test and follow-up) and the operating levels of the group (control and experiment). But the interactive effect between mathematical academic beliefs and gender $(\mathrm{P}=0.12, \mathrm{~F}=47.2)$ and the interaction effect between levels of the group (control and experiment). But the interactive effect between math performance and gender $(\mathrm{P}=0.20, \mathrm{~F}=63.1)$ and the interaction effect between mathematical performance and gender and group $(\mathrm{P}=0.88, \mathrm{~F}=0.12)$ was not significant. And shows that combining levels (pre-test, post-test and follow-up) of mathematical performance and gender factor levels (girl and boy) and group factor levels (control and experiment) do not yield different results. Therefore, the first hypothesis of the research on the difference between the experimental and control groups is confirmed but the interaction effect between gender variables and mathematical performance was not confirmed.

mathematical academic beliefs and gender and group $(\mathrm{P}=0.18, \mathrm{~F}=1.86)$ was not significant. And shows that the combination of levels (pre-test, post-test and follow-up) and gender factor levels (girl and boy) and group factor levels (control and testing) do not produce different results. Therefore, the second hypothesis of the research is confirmed only about the difference between the experimental and control groups, but not about the interactive effect between gender variables and mathematical academic beliefs.

Table 3. Results of intragroup and intergroup analysis of variance (mathematical belief)

\begin{tabular}{ccccccc}
\hline & Variable sources & SS & Df & Ms & F & Sig \\
\hline & Math Belifs & $0 / 55$ & $1 / 10$ & $0 / 50$ & $11 / 69$ & $0 / 001$ \\
& Math Belifs * Gender & $0 / 11$ & $1 / 10$ & $0 / 10$ & $2 / 47$ & $0 / 20$ \\
Intergroup & Math Belifs* Group & $0 / 80$ & $1 / 10$ & $0 / 72$ & $16 / 83$ & $0 / 001$ \\
& Math Belifs* & $0 / 08$ & $1 / 10$ & $0 / 08$ & $1 / 86$ & $0 / 88$ \\
& Gender * Group & $1 / 33$ & $31 / 01$ & $0 / 04$ & \\
Eetweengroup & Error & $0 / 05$ & 1 & $0 / 05$ & $0 / 36$ & $0 / 55$ \\
& Gender & $1 / 56$ & 1 & $1 / 56$ & $9 / 81$ & $0 / 004$ \\
& Group & $0 / 004$ & 1 & $0 / 004$ & $0 / 02$ & $0 / 86$ \\
& Gender * Group & $4 / 46$ & 28 & $0 / 15$ & \\
\hline
\end{tabular}




\section{Conclusion}

The aim of this study was to compile and design an empowerment training package with a selfdetermination approach and its effectiveness on the performance and mathematical beliefs of male and female students (with low performance in this course) was investigated. The results showed that the empowerment training package with selfdetermination approach was effective on improving the performance and mathematical beliefs of lowperforming male and female students in this course. It was also investigated in this study that the empowerment training package with selfdetermination approach is effective over time.

The results of this research are in line with the results of the research, Research by Leon, Nunes and Lemon (2015), Abbasi and Shahni Yilagh (1396), Brandenberg, Neuer and Hascher (2018) and Frost (2007) but the results of this study were not in line with the results obtained from Farzan (2013) research. In general, it can be concluded that empowerment package training with selfdetermination approach can provide a very good platform for increasing performance and improving academic math beliefs of male and female students. Feeling empowered or in other words self-confident, according to Shah Mohaghegh, is the key to change in this study. Desi and Ryan (2008) argue that the self-determination approach is not just a way of thinking, but creates a style (life orientation) in the person through that the person has a stable ability and self-regulating personality. Self-determination skills training begins with three needs, the need for autonomy, the need for competence, and the need for communication; in addition, in the process of teaching students self-determination skills using decision-making techniques, Goal setting, planning, acting on goals and plans, Understanding the source of causality (correct documents about failures and successes), they create solutions to solve their problems and to deal appropriately with the environment, especially in dealing with academic (mathematical) problems.

Empowerment training package with selfdetermination approach is a training package that relies on and supports aspects of self-efficacy and empowerment. Empowerment training package with low self-determination approach helps male and female students gain a better understanding of their decisions, goals, and reasons for failure; have a sense of self-worth and show a higher commitment to dealing with issues. experience more success in advance. Make more connections with yourself, focus more on its interpersonal relationships, have more empathy with family and classmates. Finally, they perform better in life and they know themselves and their abilities better than before and they are convinced of them.

\section{Ethical Considerations}

Compliance with ethical guidelines: This article is extracted from the Ph.D. dissertation of the first author, which was approved under No. 11920705962013 in the Educational Psychology Department, science and research Branch, Islamic Azad University with the proposal approval date of 01.02.2019. The permission for its being carried out on the participants was issued by Tehran Education Administration in 2019. Ethical considerations like gaining the informed consent of the participants and the confidentiality were observed in this research

Funding: This study was conducted as a Ph.D. thesis with nofinancial support.

Authors' contribution: The first author was the seniorauthor, the second one was the supervisors and the third one was the advisor.

Conflict of interest: There is no conflict of interest in this study. Acknowledgments: We would like to appreciate the supervisors, the advisor, the participants, and the authorities of Tehran Education Administration (sixth district) as well as the educationists and school consultants. 


\section{طراحى و تدوين بسته آموزشى توانمندسازى (با رويكرد خودتعيين زرى) و اثربخشى آن بر عملكرد و باورهاى رياضى (خي

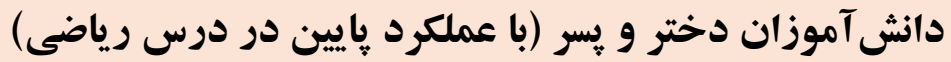

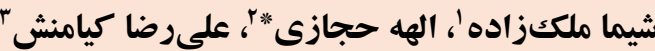

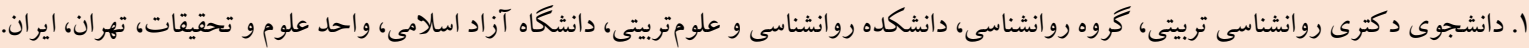

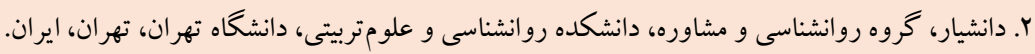

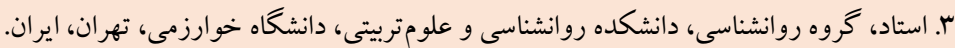

\section{جكيده}

زمينه: تحقيقات متعددى به تأثير آموزش خود تعيين گرى بر يادگيرى دانش آموزان برداختهاند اما بزوهشى كه به طراحى و تدوين بسته

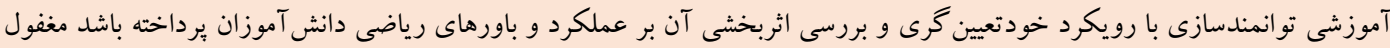
مانده است هدف: يُزوهش حاضر با هدف طراحى و تدوين بسته آموزشى تو انمندسازى با رويكرد خودتعيين گرى و بررسى اثربخشى آن بر عملكردو و

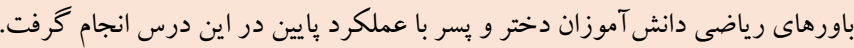

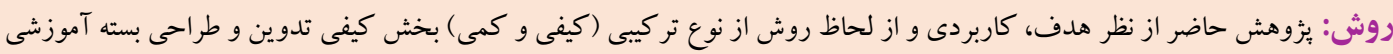

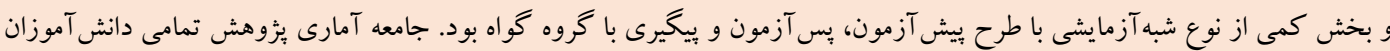

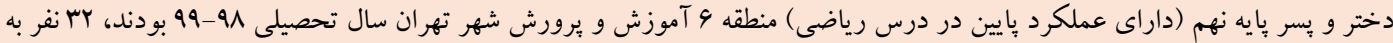

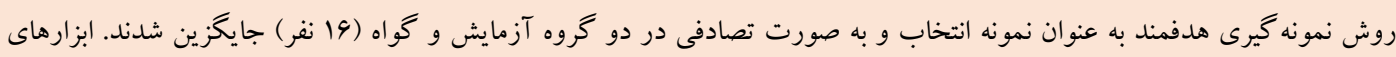

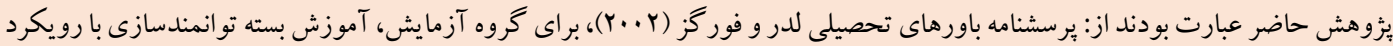

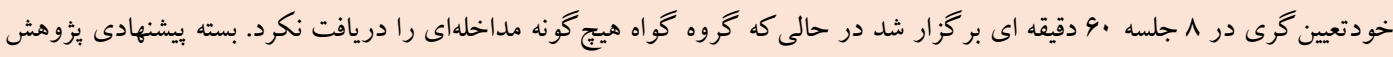

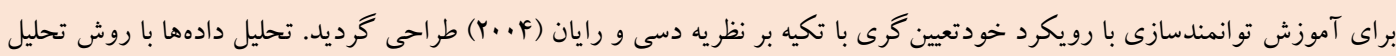

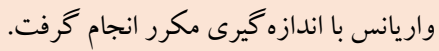

يافته ها: بسته آموزشى توانمندسازى با رويكرد خودتعيين گرى طراحى شده بر عملكرد و باورهاى رياضى دانش آموزان دختر و يسر (با بان

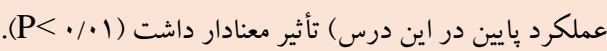

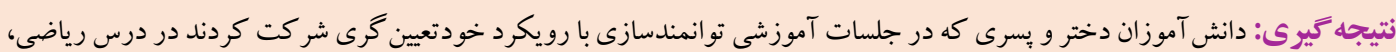
عملكرد بهترى نشان داده و باورهاى تحصيلى آنها در اين درس بهبود يافت، بنابر اين ييشنهاد مى شود جزء برنامههاى آموزشى نهادهاى تعليم و تربيتى از جمله سازمان آموزش و برورش در نظر گرفته شود.
مشخصات مقاله

كليدوازهها: بسته آموزشى تو انمندسازى، خودتعيين گرى، عملكرد تحصيلى، باورهاى رياضى،

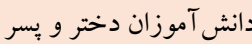

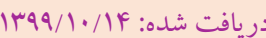

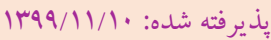

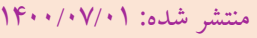

* نويسنده مسئول: الهه حجازى، دانشيار، دانشيار، گروه روانشناسى و مشاوره، دانشكده روانشناسى و علومتربيتى، دانشكاه تهران، تهران، ايران. رايانامه: ehejazi@ut.ac.ir 
رابطه صحيح و دوستانه با دانش آموز، ممانعت والدين از تحصيل، دورى از

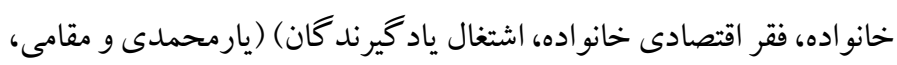

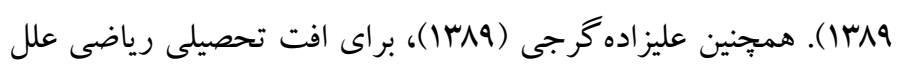

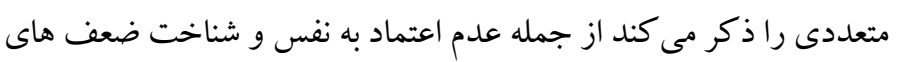

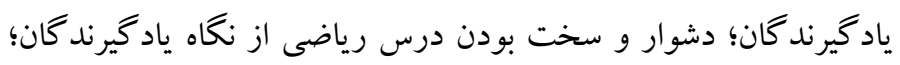

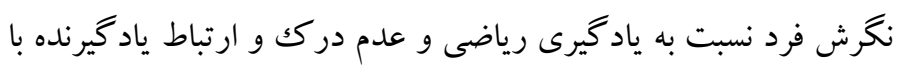

رياضى.

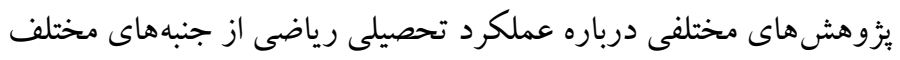

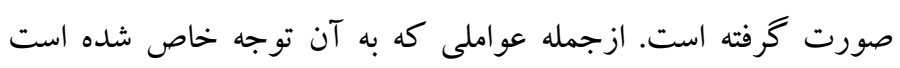
باورهاى است كه دانش آموزان در مورد ماهيت رياضيات و تكاليف آن دارند. نخرش ها و باورها نقش عمدهاى در همه امور زندكى ايفا مى كنند و

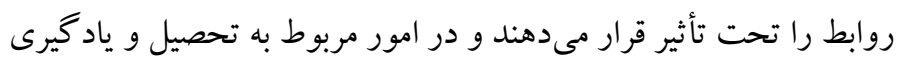
و دروسى مانند رياضى نيز از اين امرمستثى نيستند در حالى كه نه تنها استعداد رياضى افسانه است بلكه حتى جيزى به نام مغز رياضى نيز وجود لني

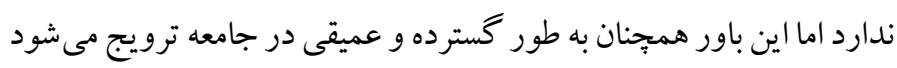

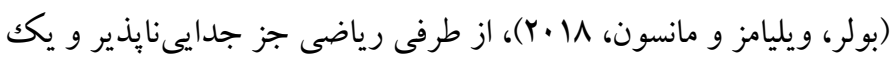
موضوع محورى در آموزش عمومى و برنامه درسى مدرسهاى است، كه ونه

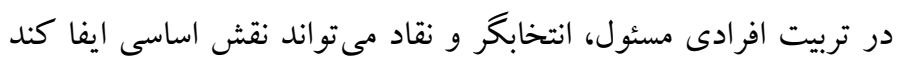

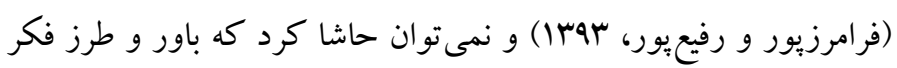

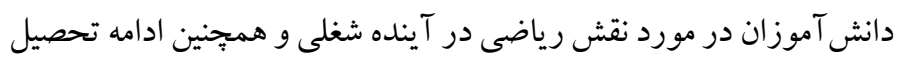

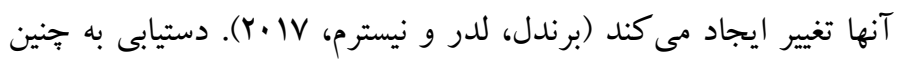
اهداف مربوط به آينده، وابسته به شناخت و تغيير نخرش دانش آنش آموزان نسبت به رياضى است. فردى كه باور دارد كه در زمينه رياضى مى تواند موفق باشد، به راستى عملكرد بهينه در درس رياضى خو اهد داشت. بـ باورها

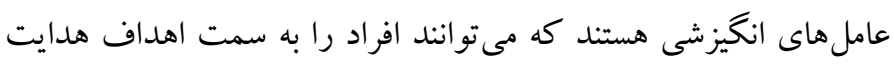

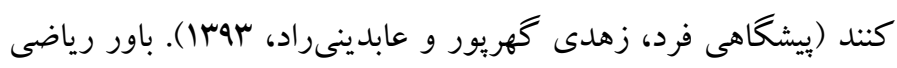
يعنى تصورات شخصى كه در مورد طبيعت رياضيات وجود دارد و نيز تصوراتى كه فرد در زمينه ياددهى و ياد گيرى رياضى دارد به عبارت ديخر باور، كيفيتى ذهنى است كه در واقع فرد به عنوان حقيقت آن را مي يذيردة

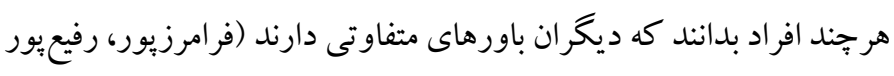

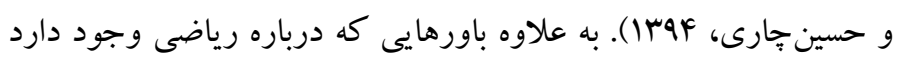

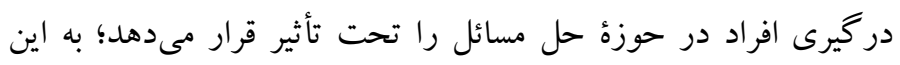

مقلفمه

توسعه جوامع در گرو دانش سازمان يافتهاى است كه به مدد يُزوهش به

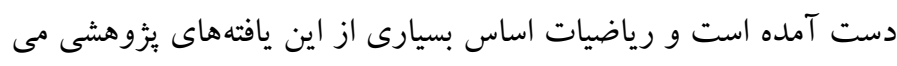

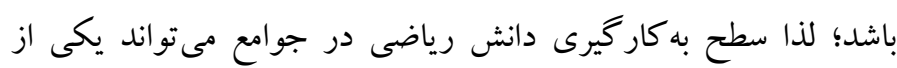

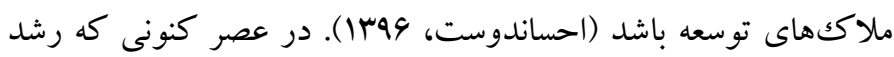
روزافزون فناورى تحولات شگگفى را در زندگى انسانها به وجود آوردهه

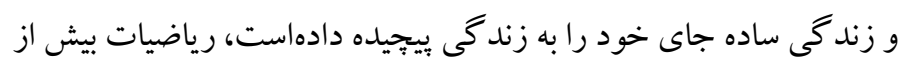
يُش جاى خود را در همه زمينه هاى اجتماعى و صنعتى باز كرده و انسان

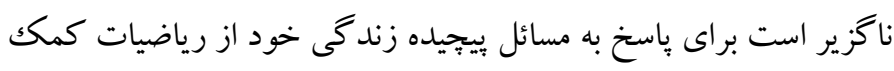

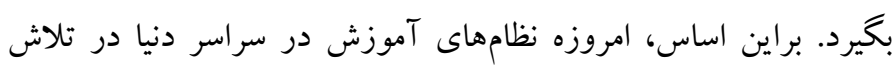

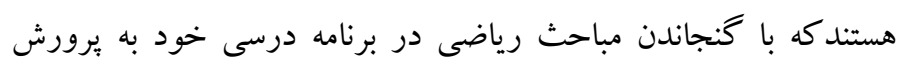

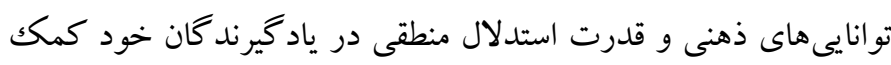

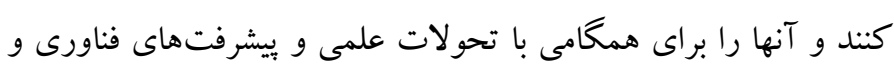

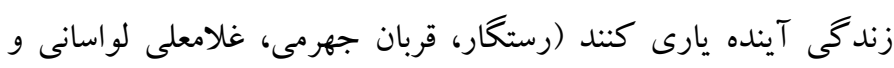

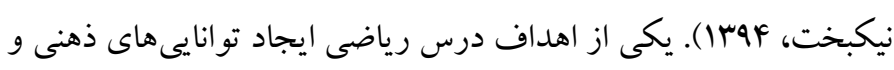

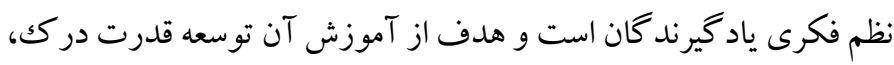

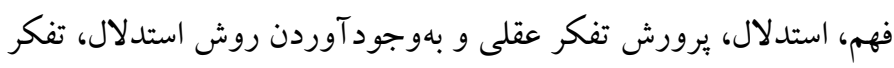

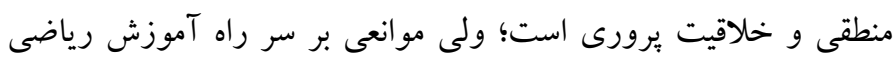

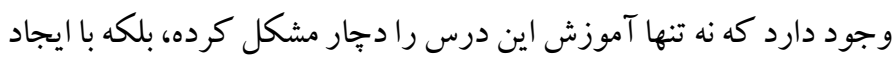
افت رياضى مسير زندگى افراد مختلف را تحت الشعاع قرار داده است.

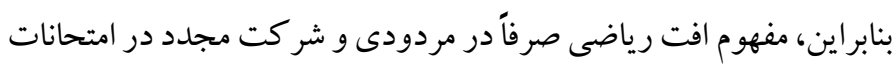

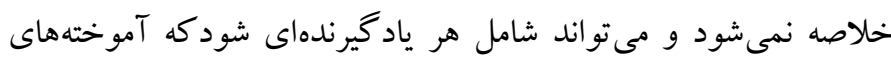

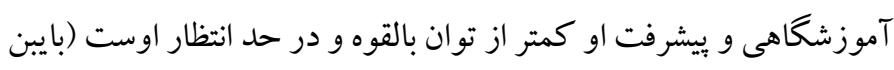

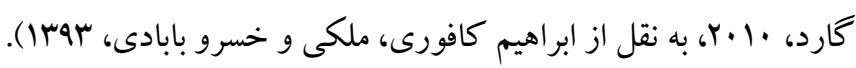

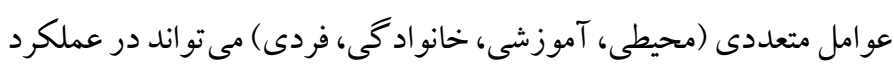

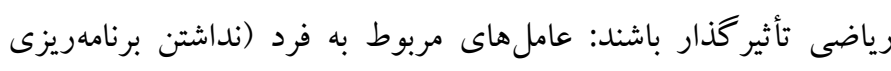

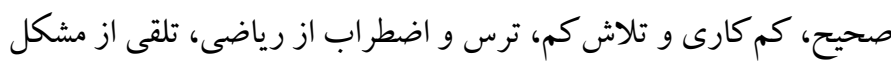

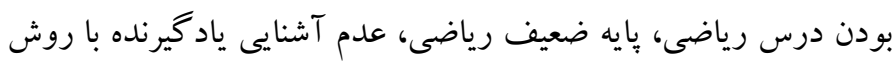

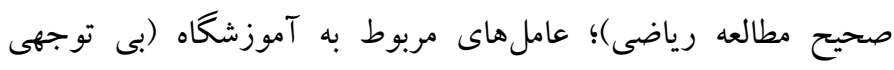
مدرسان، حل نكردن تمرينهاى كتاب رياضى، درس ندادن تمام مطالب رئب

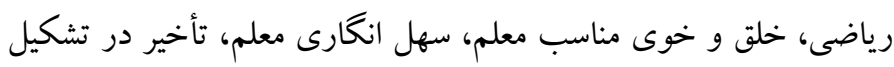

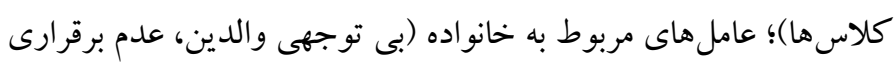


مطالعات گوناكون نشان مىدهد توانمندسازى فر آيندى است جندبعدى كه

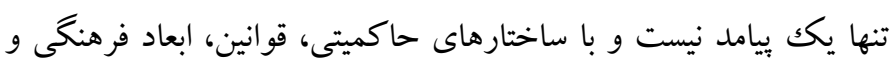

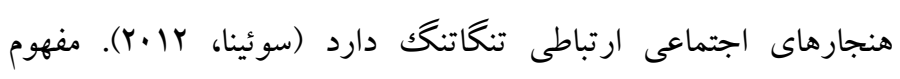
توانمندسازى ابعاد مختلفى دارد؛ مانند اجتماعى، اقتصادى، روانشناسى،

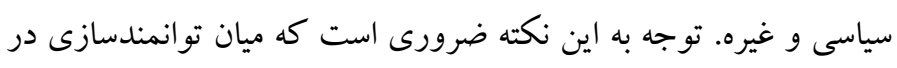

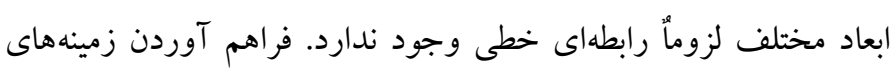

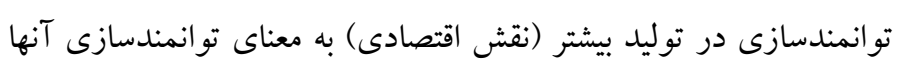

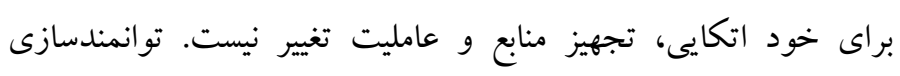
روانشناختى مفهومى يويا و متغير و جندبعدى است و ماهيتى ييجيده دارد. ادبيات توانمندسازى را مىتوان به جهار دسته تقسيم نمود (قلىيور،

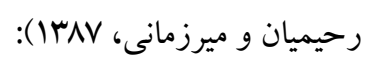

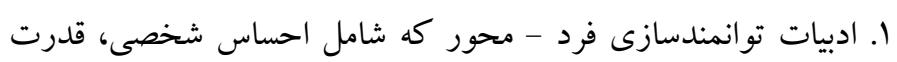
شخصى، خود تعيينى و ساير متغيرهاى شناختى است.

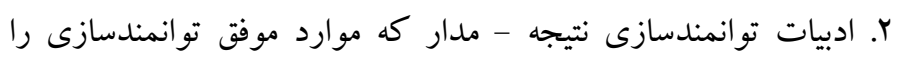
بروسى مى كند.

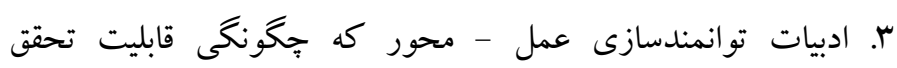
توانمندسازى را از طريق كاهش سطوح سازمانى، درگير كردن، ايجاد تعهد، تيمسازى و مداخله توضيح مى دهد.

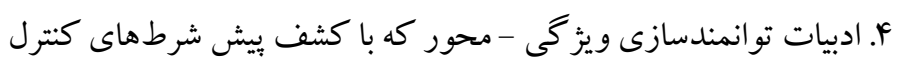
و قدرت، اعتماد و ظرفيت، بِاسخكويى، صداقت و ريسك يذيّيرى مشخص مى شود. در اين بززوهش بيشتر بر تو انمندى روانشناختى تأكيد مى شود. توانمندسازى روانشناختى اولين بار در ادبيات مديريت وارد شد. اسبريتزر (1990-

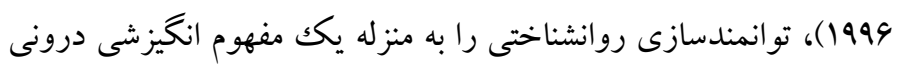
متشكل ازينج بعد شايستخى، خودمختارى (حق انتخاب)، معنادار بودن،

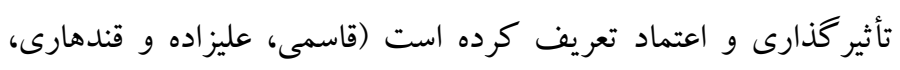

(I) TV

اسبريتزر (1990) يكى از ابعاد توانمندسازى را خود تعيين گرى معرفى كرده

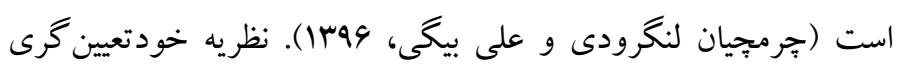

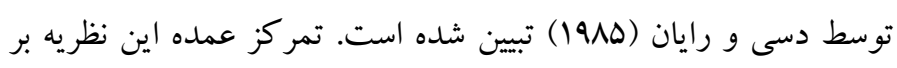

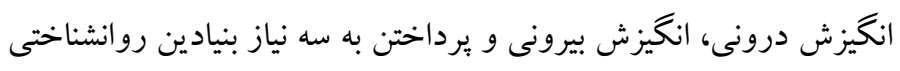
(نياز به خودمختارى، احساس شايستخى و ارتباط) در انسان مىباشد. تأكيد
صورت كه وقتى مسئلهاى مطرح مىشود اخر از عنوان مسئله سخت در مورد آن استفاده شود، افراد زيادى از همان ابتدا هيج تمايلى به حل و و حتى دئى

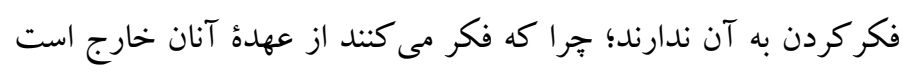

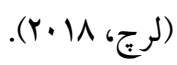
همانطور كه كفته شد باورها نقش مهمى در عملكرد بازى مى كنند و

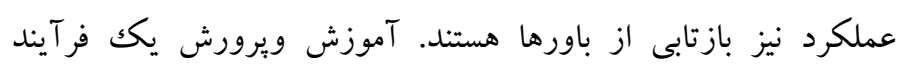

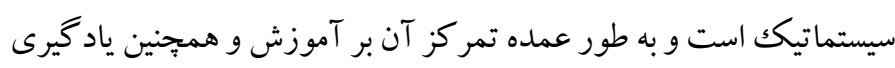
است. روشهاى آموزش در امر يادگيرى نقش كليدى دارند و دادن

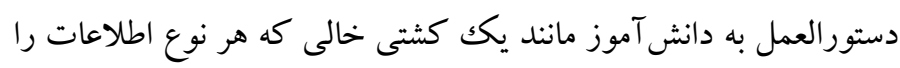

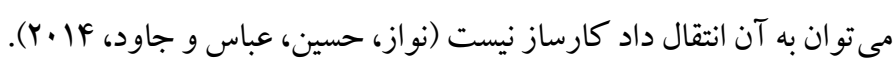

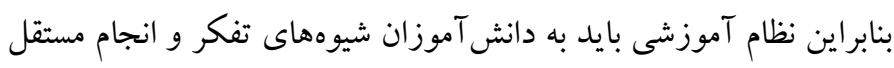

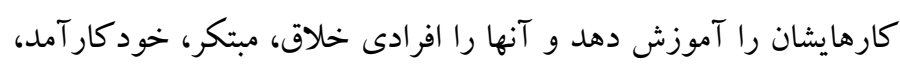

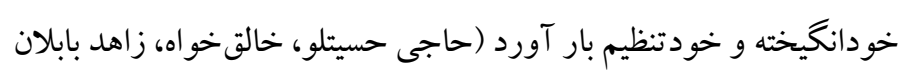

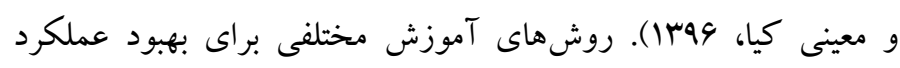

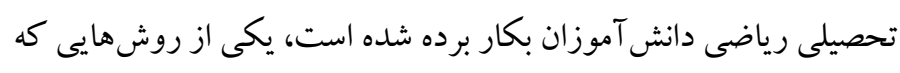

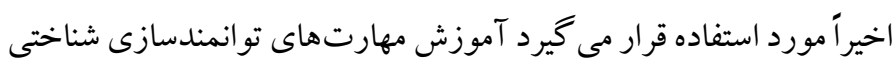

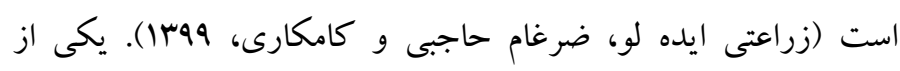

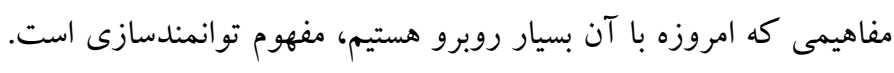

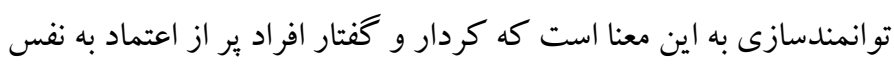

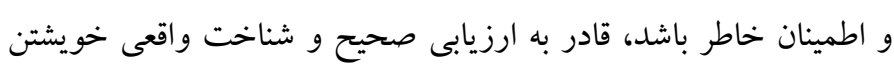

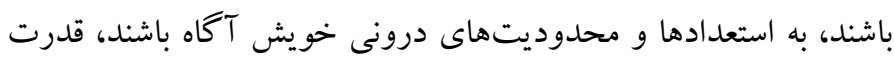

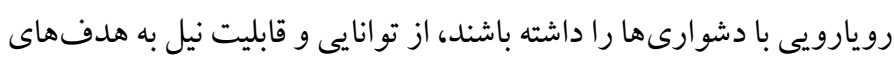

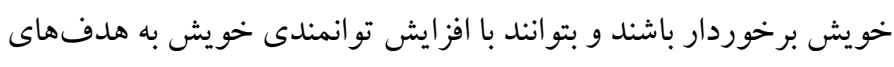

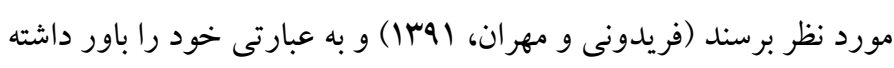

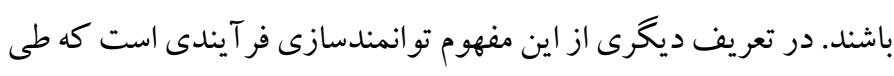
آن فرد كنترل بيشترى بر مقتضيات زندكى خود بيدا مى كنند و به دنبال آن

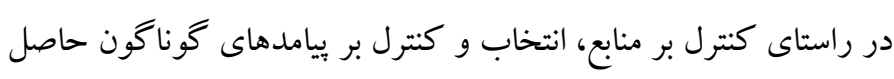

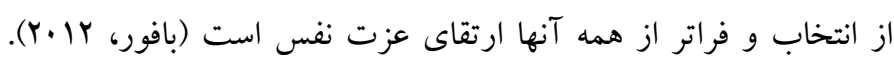
بنابراين اكر بتوان دانش آموزان را با مفهوم تو انمندسازى آشنا ساخت، به به آنه

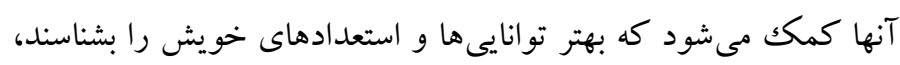

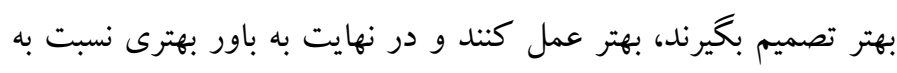
خويشتن برسند. 
در تعاملات با محيط اجتماعى، كسب فرصت براى تمرين و ابراز تو انايى هاى خويش، تو انايى دسترسى به يِيامدهاى مطلوب و و احساس قابليت تأثير كذارى و تسلط بر محيط مىباشد (سل ايبارا- رويلارد و كوييبر،

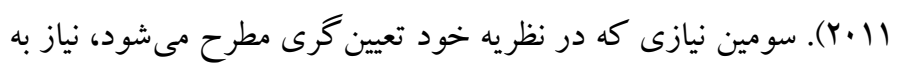

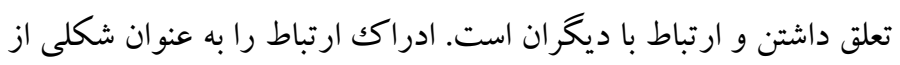

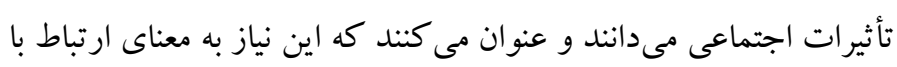
كسانى است كه براى فرد اهميت داشته و يا از او حمايت مى كنند (خوارزمى، كارشكى و عبدخدايى، |وسا). در واقع اين نياز متوجه وييوند

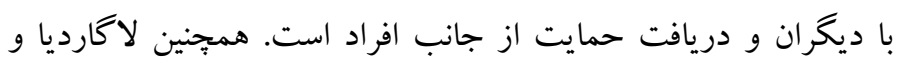

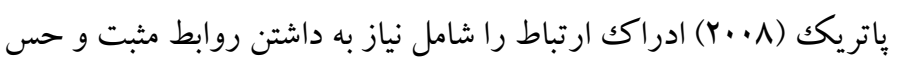
تعلق به گروه يا جامعه مى دانند. تحقيقات زيادى خود تعيين گرى را به عنوان يكك سازه روانشناختى و يكك داند نظريه انخيزشى را در بهبود باورهاى رياضى مؤثر دانستهاند (برندنبر گرى،

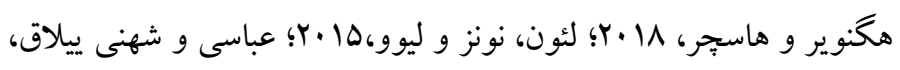

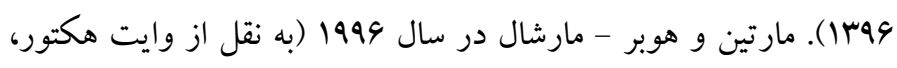

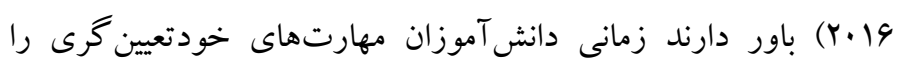
مى آموزند از نيازها و علائق خود شناخت بيدا كنند و بيشتر از قبل خود و و دهائ تو انايى هايشان را باور مى كنند.

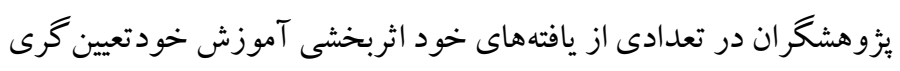

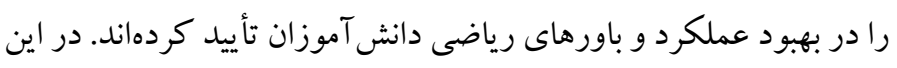

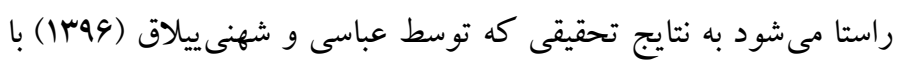

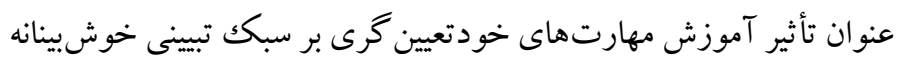

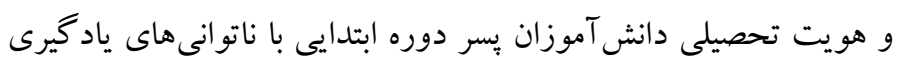

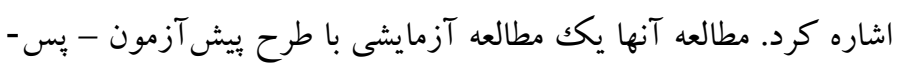

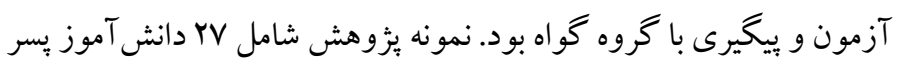

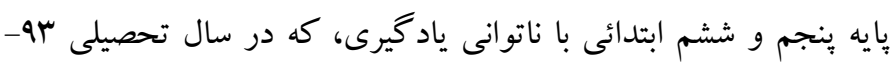

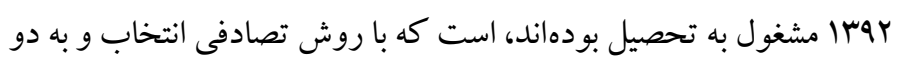

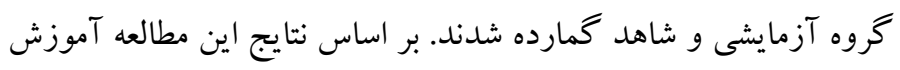

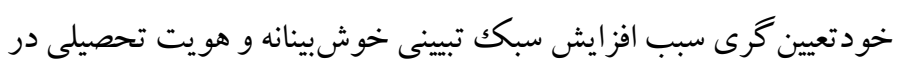
دانش آموزان شد.

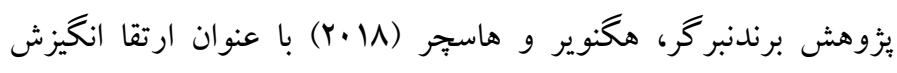

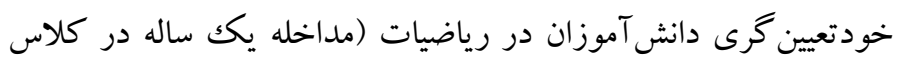

اين نظريه بر ميزانى است كه رفتار انسانها ارادى يا خود تعيين گر باشد. يكى

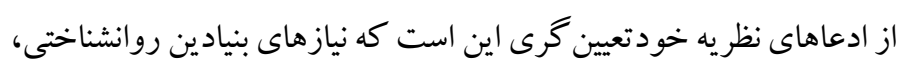

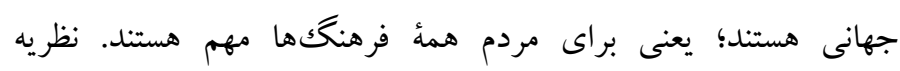

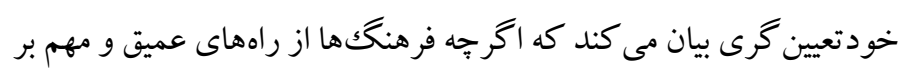

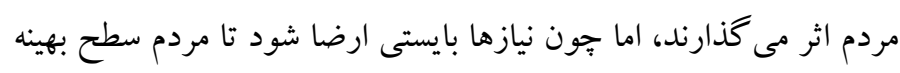

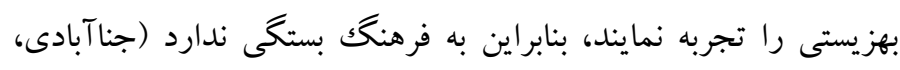

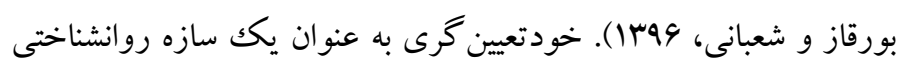

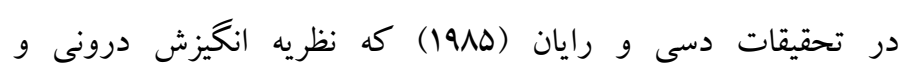

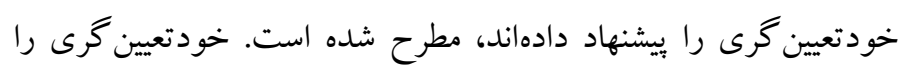

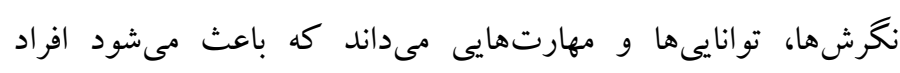
هدف هاى خود را انتخاب كرده و براى رسيدن به آنها تلاش كنئن

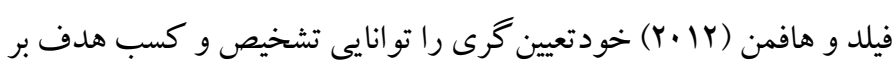
مبناى شناخت و ارزشمند دانستن خود تعريف ميى كنند، براى اينكه دانش آموزان خودتعيين گر شوند بايد نقاط قوت و ضعف خود ردان را بشناسند،

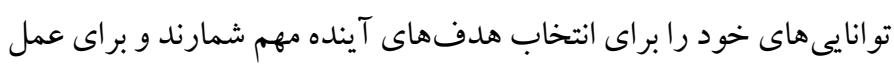

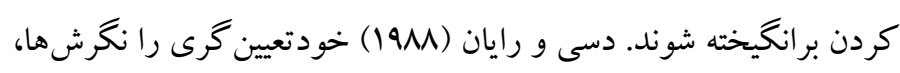
توانيىها و مهارتهايى مى داند كه باعث مى شود افر اد هدف هاى خون خود را انتخاب كرده و براى رسيدن به آنها تلاش كنند. بنا به نظر آنان ماند

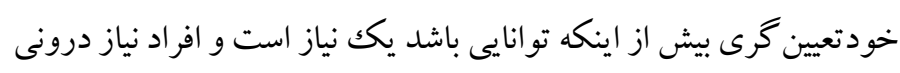

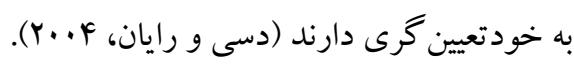
اولين نيازى كه در نظريه خودتعيين گرى مطرح مىشود، نياز به وديه

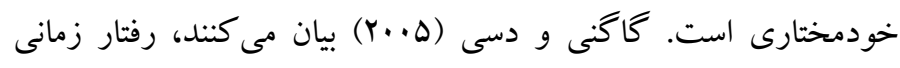

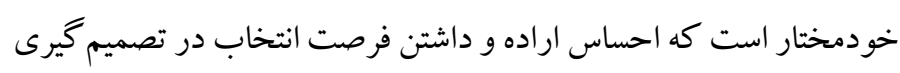

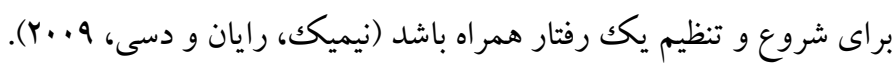

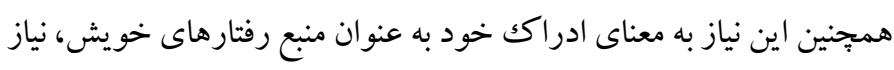

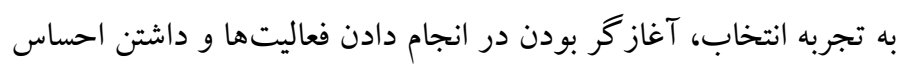

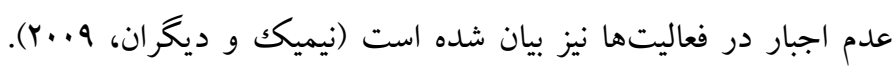

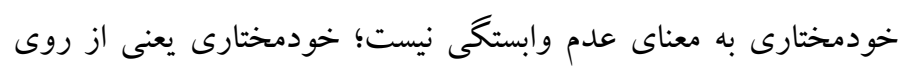

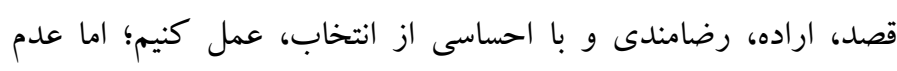

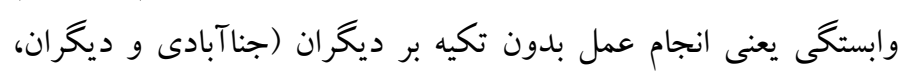

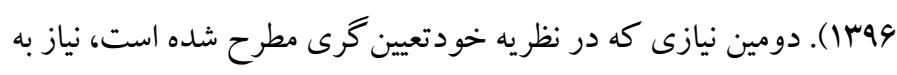
شايستخى مىباشد. نياز به شايستخى منعكس كننده نياز به مؤثر بودن فرد نياري 
رياضى دانش آموزان دختر و بسر صورت نخرفته است. لذا ارائه يك بسته

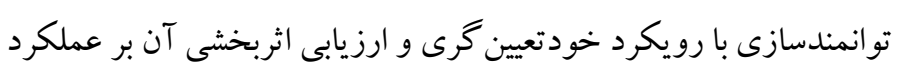

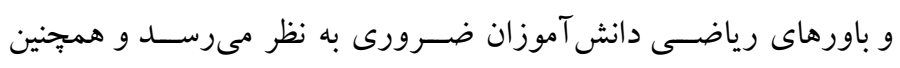

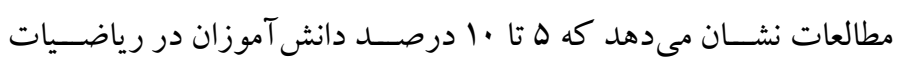

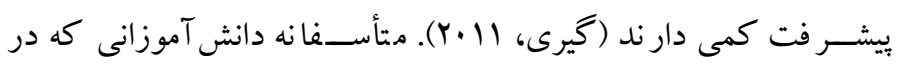

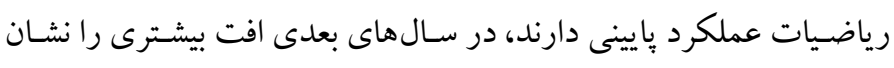

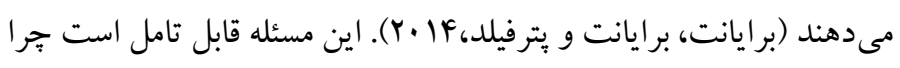

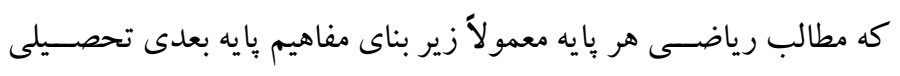

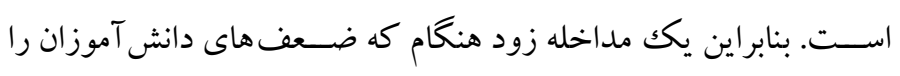

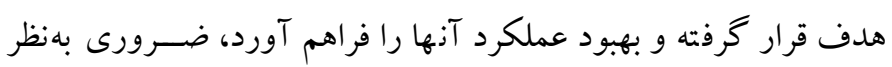

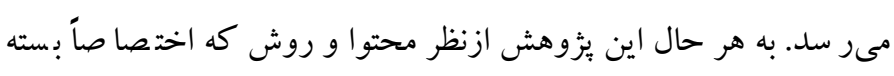

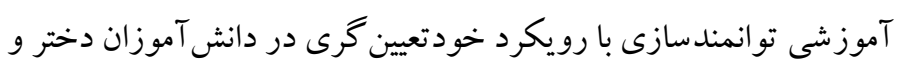

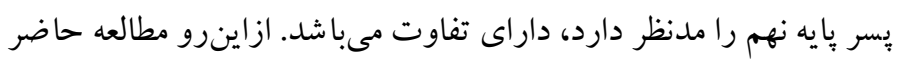

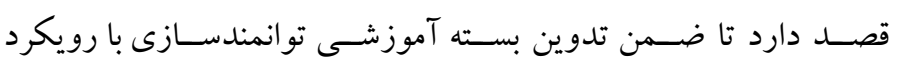

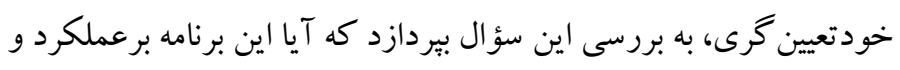

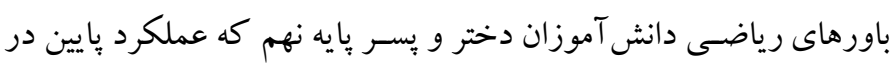

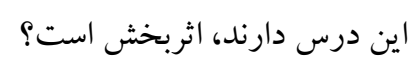

روش الف) طرح هُؤش و شر كت كنند كان: ئزوهش حاضر از نظر هدف، كاربردى بوده و از لحاظ روش از نوع تر كيبى (كيفى و كمّى) شامل بخش كيفى از نوع تدوين و طراحى بسته آموزشى توانمندسازى با رويكرد

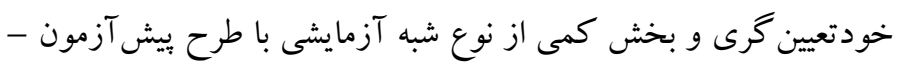

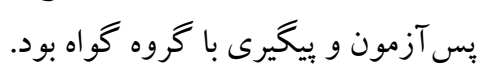

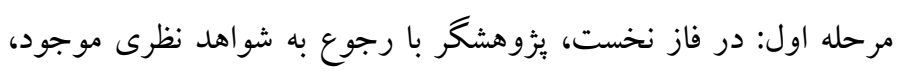

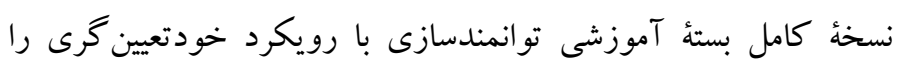

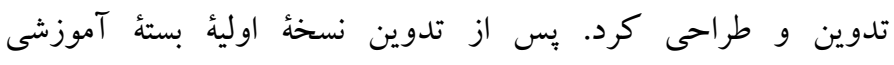

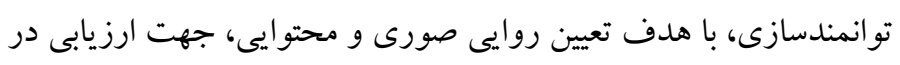

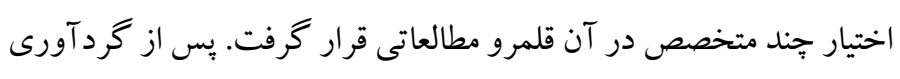
نظرات ارزيابانه متخصصان و اعمال دقيق بيشنهادها اصلاحى بسته جهت

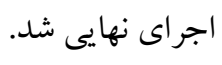

درس) به اين نتيجه رسيدند كه هر دو جنس بعد از آن كه در معرض

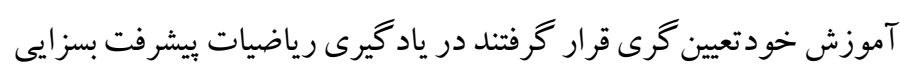
داشتند.

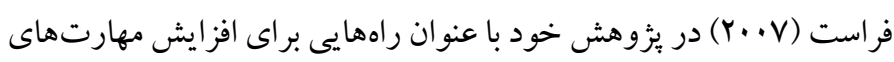

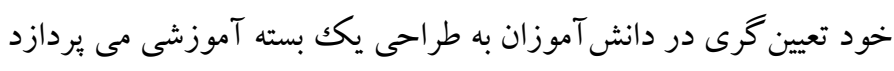

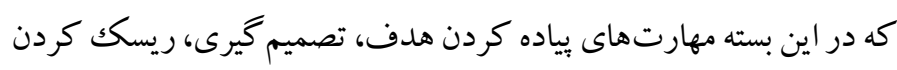

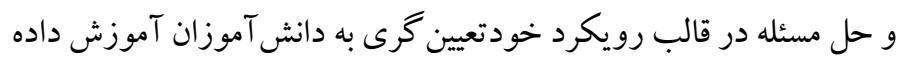
مىشود. يافتهاى يُزوهش نشان مىدهد كه زمانى كه دانش آموزان اين مهارت ها را ياد مى گيرند و بكار مىبندد، موفقيت بيشترى در تحصيل بيدا مى كنند.

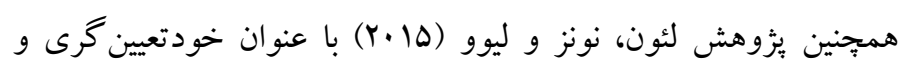

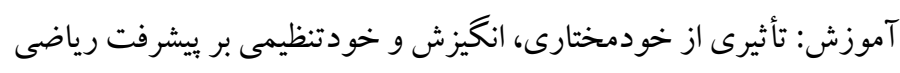

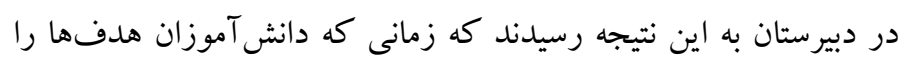

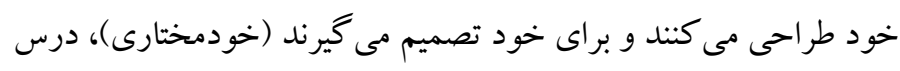

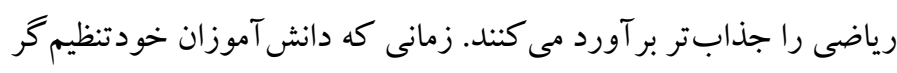

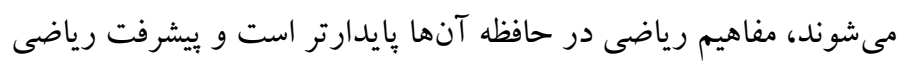
در آنها ديده مى شودد.

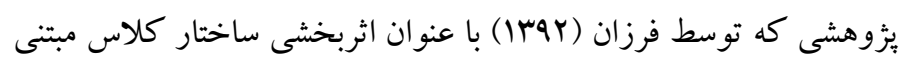

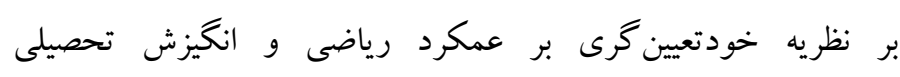

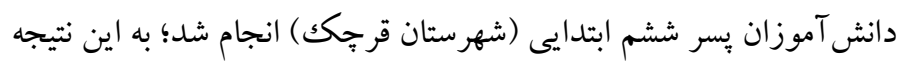

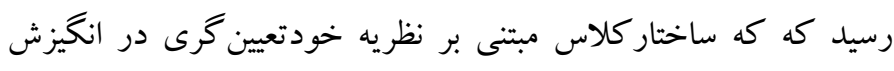

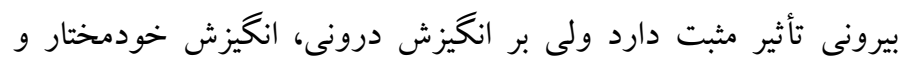

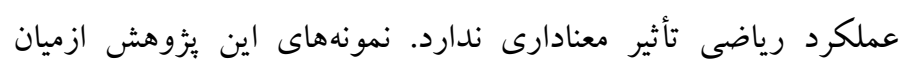

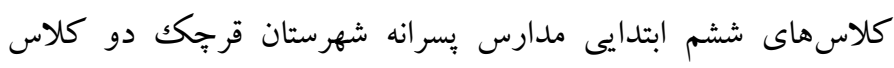

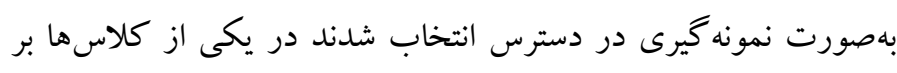

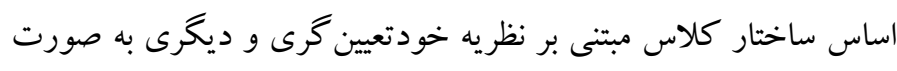

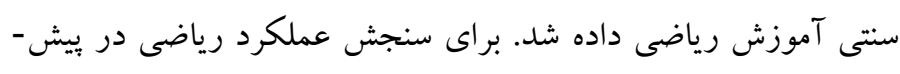

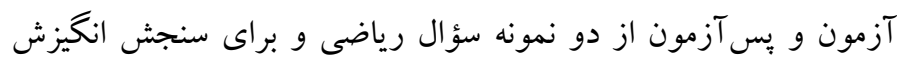
تحصيلى در بيش آزمون و پِ آزمون از مقياس انخيزش تحصيلى ولرند استفاده شده است. (AMS) با بررسى بيشينه يزوهش، اين مطالعات هيج كدام اثربخشى بسته آموزشى اندى

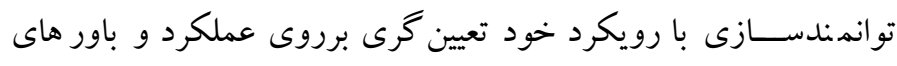


آموزشى بود. به جهت رعايت اصل اخلاقى عدالت در بزوهش توسط

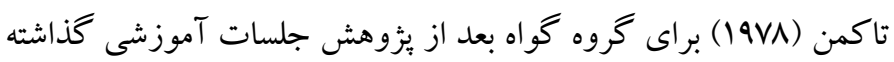

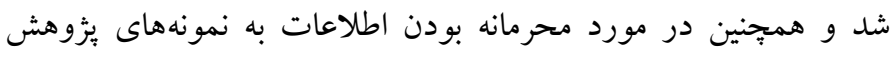

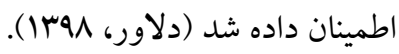
لازم به ذكر است كه دادههاى متغير عملكرد رياضى از طريق نمره آزمون رياضى دانش آموزان بدست آمده است كه توسط دبيران درس رياضى به يثزوهشخر گزارش داده شده است. نمرات عملكرد رياضى بيش آزمون از

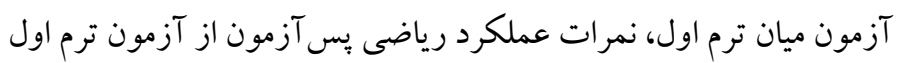
و نمرات عملكرد رياضى بيخيرى از آزمون كلاسى بدست آمده است. همجنين دادههاى متغير باورهاى رياضى از يرسشنامه باورهاى تحصيلى

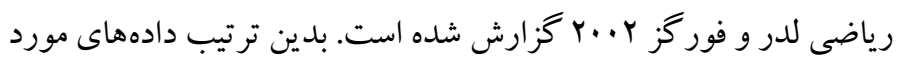
نياز جمع آورى و درنهايت باستفاده از نرمافزار SPSS نسخه وب و آزمون

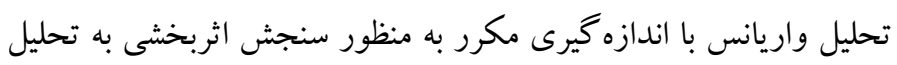
يافته ها برداخته شد.

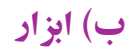

برسشنامه باورهاى تحصيلى رياضى: اين مقياس توسط لدر و فور زز در سال

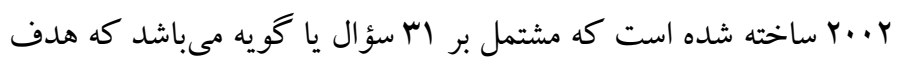
آن بررسى مؤلفه باورهاى تحصيلى رياضى دانش آموزان است و بهصورت استه

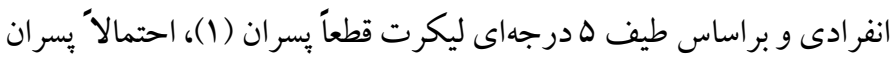

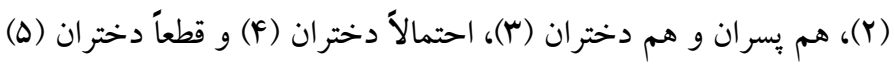

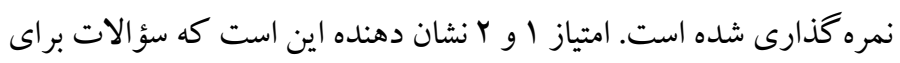

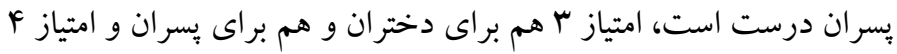

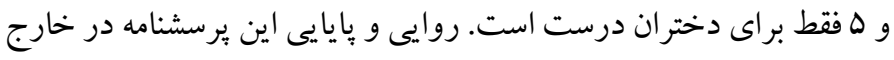

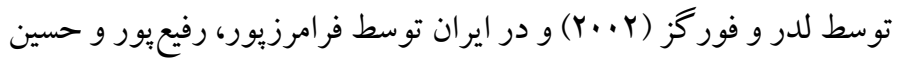

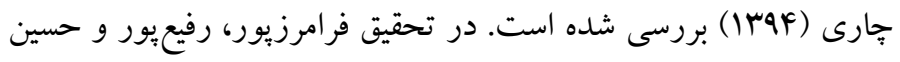

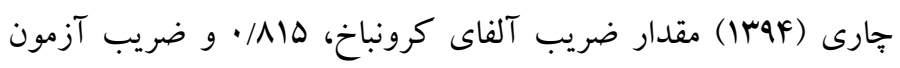

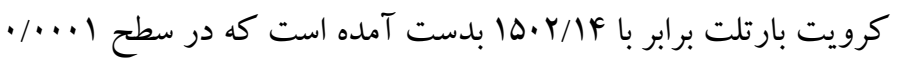

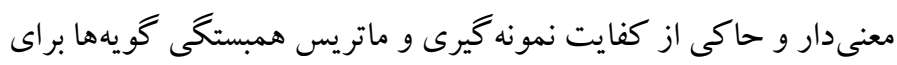
انجام تحليل عاملى بوده است. براى روايى نيز از روايى محتوايى استفاده

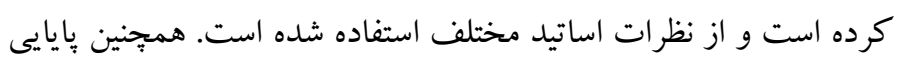
برسشنامه يا قابليت اعتماد آن با استفاده از روش اندازه كيرى آلفاى كرونباخ
در فاز دوم تحقيق، اثربخشى بسته آموزشى توانمندسازى با رويكرد

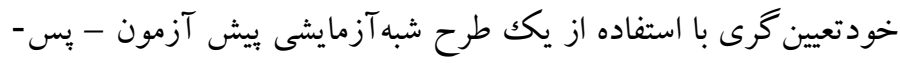

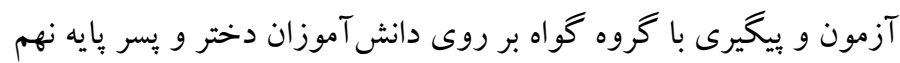

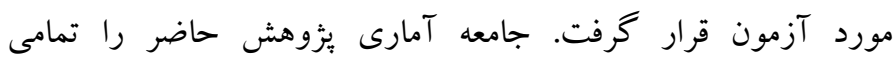

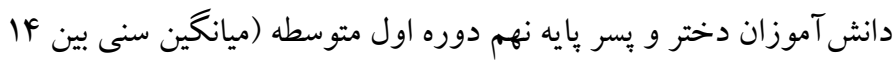
و ها سال) منطقه 9 آموزش و برورش شهر تهران سال تحصيلى داراى عملكرد يايين در درس رياضى هستند، تشكيل دادهاند. براى مشخص

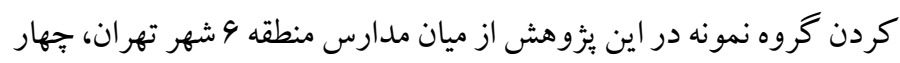

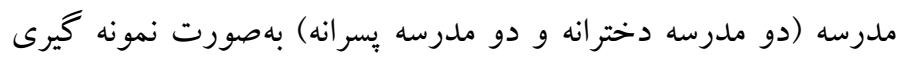

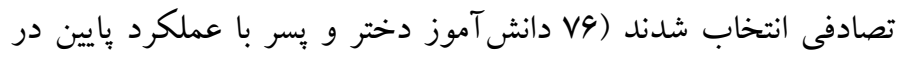
درس رياضى) و سيس از مدارس انتخاب شده بصورت نمونه گيرى هدفمند

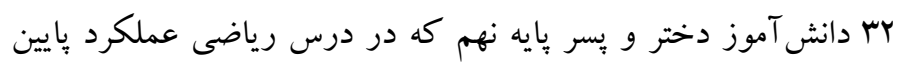

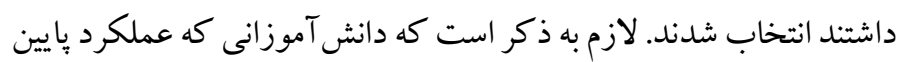
در رياضى داشتند توسط دبيران اين درس به ئزوهشخر معرفى شدند و

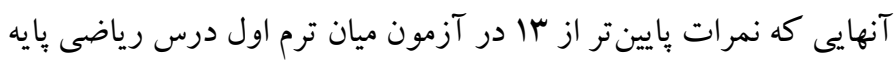

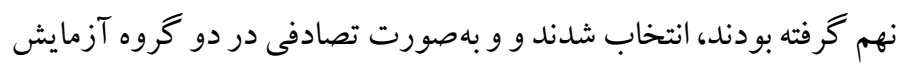

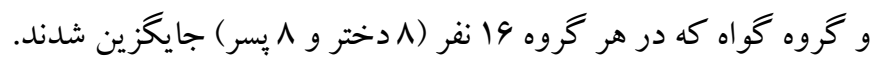

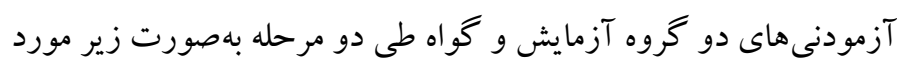

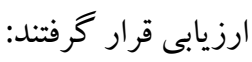
الف. انجام ييش آزمون قبل از شروع جلسات آموزشى مرنى

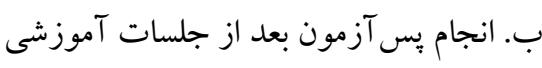

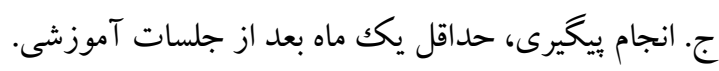

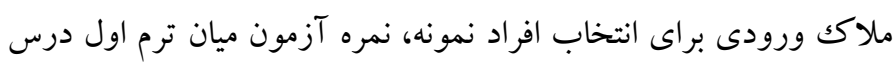

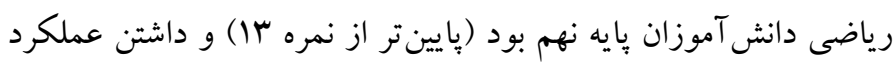

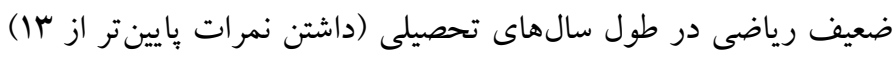

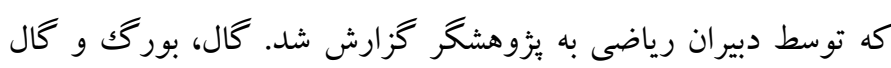

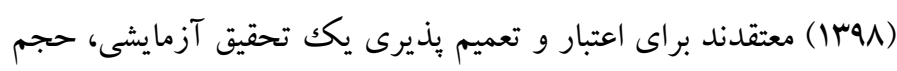

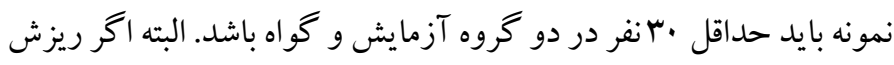

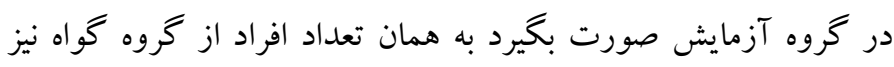

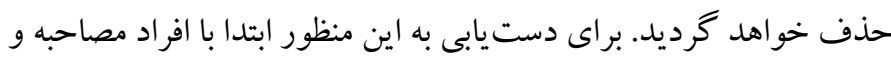

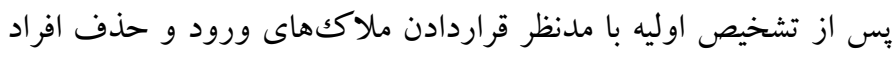
انتخاب شدند. ملاكك خروج از يزووهش داشتن دو جلسه غيبت در جلسات 
يرورش به هدفهاى دقيق آموزشى است. از نظر ميخر نقش تحليل غايت اين است كه غير قابل تعريف را قابل تعريف و غيرقابل لمس را ملموس مدسي

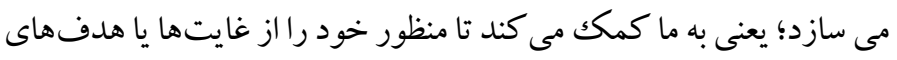

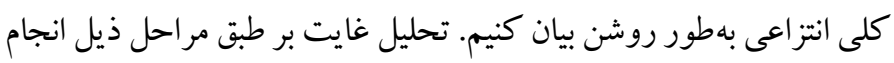

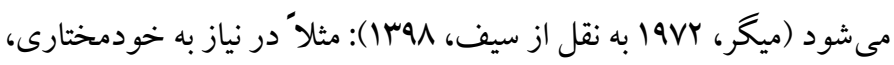
تعريف و شناخت خودمختارى، شناخت زير مؤلفهاى آن از جمله درك انتخاب در مورد خويش، اراده (احساس آزاد بودن) و دركك منبع عليت درونى؛ همجنين شناسايى بيش نيازهاى هركدام از زير مؤلفهاى

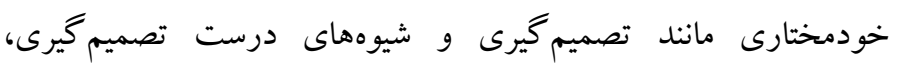

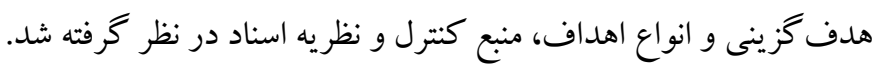
تعيين غايت يا هدف كلى: غايت يا هدف كلى بر حسب نتيجه يا يُامد

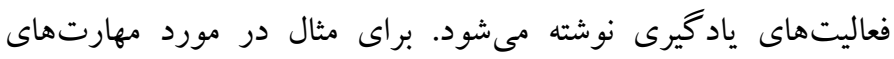

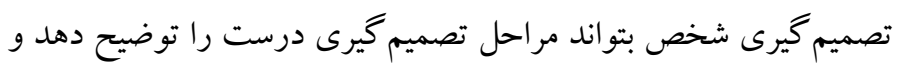
در مواقع بروز مشكل از مهارت تصميم گيرى مناسب استفاده نمايد.

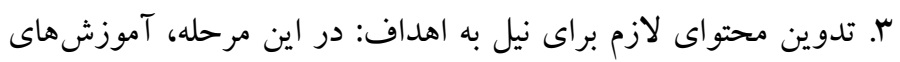

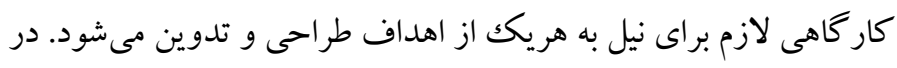

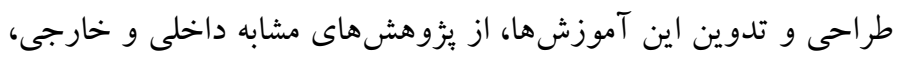

برنامههاى مرتبط با موضوع و تجارب صاحبظر ان استفاده خو اهد شد.

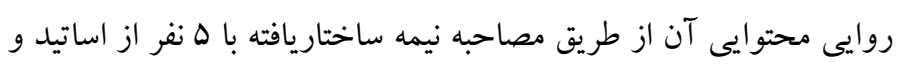

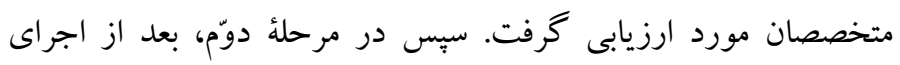

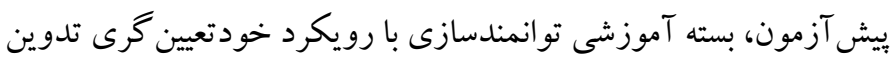

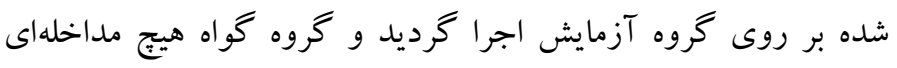
دريافت نكرده و به روال عادى خود ادامه داد. در نهايت بعد از بايان

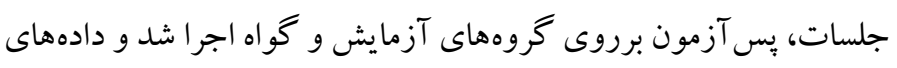
بهدست آمده از نمونهها آماده تحليل شد. خلاصه جلسات بسته آموزشى برونى توانمندسازى با رويكرد خودتعيين گرى در جدول زير ارائه شده است:
محاسبه شد. يايايى محاسبه شده براى ييش آزمون باورهاى تحصيلى رياضى

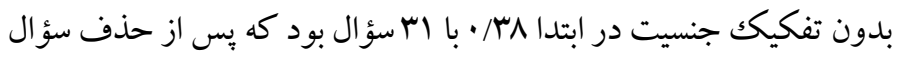

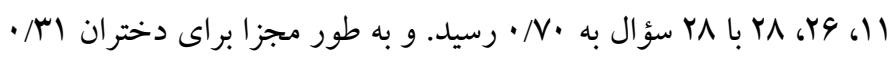

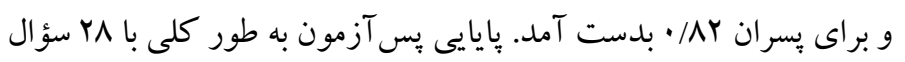

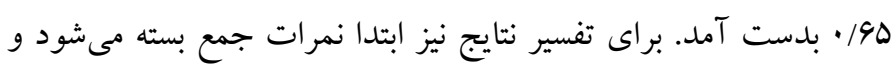

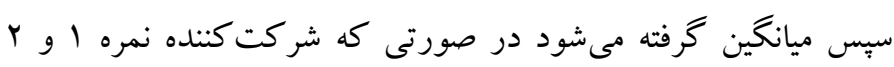

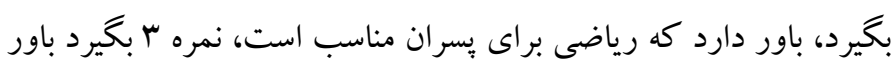

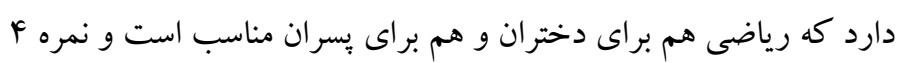

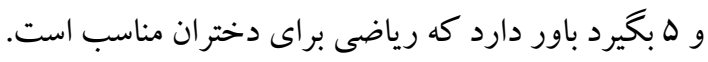

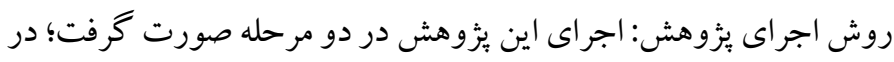

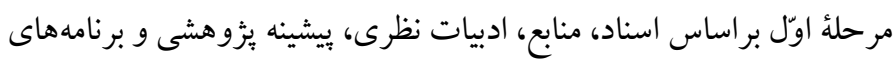

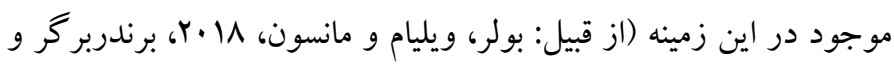

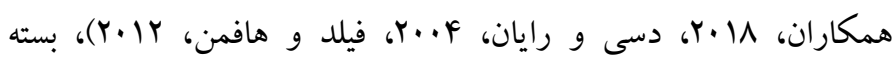

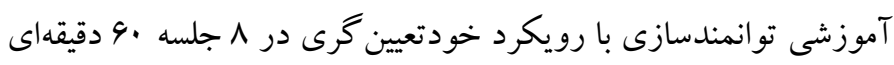

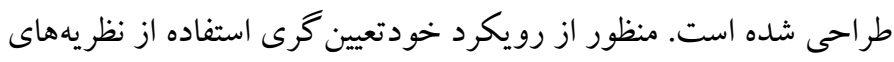
مطرح در رابطه با اين مفهوم به ويزه نظريه خودتعيين گرى دسى و روايان است. مراحل تدوين و طراحى بسته آموزشى مربوطه به صورت زير بود: ابتدا

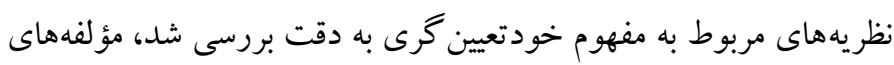

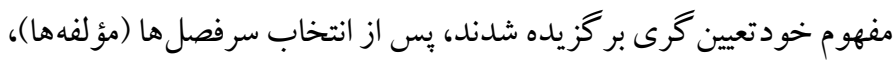
سرفصل هاى دقيق با استفاده از روش تحليل غايت ميخر (19VY) نوشته شدند كه مراحل به قرار زير است:

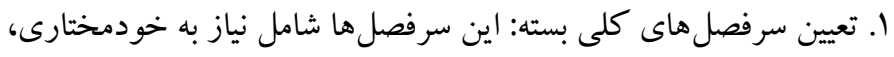
نياز به شايستخى و نياز به ارتباط مى باشند.

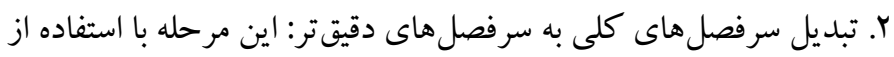
روش تحليل غايت اهداف كلى به اهداف دقيقتر انجام مى شود. تحليل

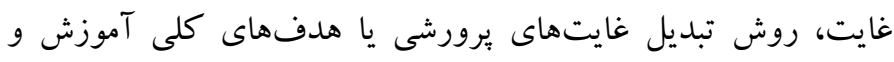

جدول ا. نمايیى كلى از خلاصه جلسات بسته آموزشى توانمندسازى با رويكرد خودتعيين كرى

\begin{tabular}{|c|c|c|c|}
\hline تكاليف & محتواى آموزشى & اهداف & عنو ان جلسه \\
\hline \multirow{2}{*}{-} & معرفى كلى برنامه آموزشى، بيان قواعد كار گاه، & آشنايى با دانش آموزان، بيان & 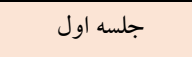 \\
\hline & معرفى سرفصل جلسات، اجراى ييش آزمون & اهداف كار كاه و ايجاد انكيزه & برقرارى ارتباط \\
\hline در يكك باراگر اف نظر خود را در رابطه با مريم & معرفى و شرح زندگى نامه يكك رياضيدان زن مشهور & آموزش خودمختارى و شيوه & 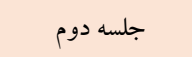 \\
\hline ميرزاخانى بنويسند. & جهانى (مريم ميرزاخانى)، تعريف خودمختارى و & درست تصميم گيرى & خودت تصميم بخير \\
\hline
\end{tabular}




\begin{tabular}{|c|c|c|c|}
\hline تكاليف & محتواى آموزشى & اهداف & عنوان جلسه \\
\hline 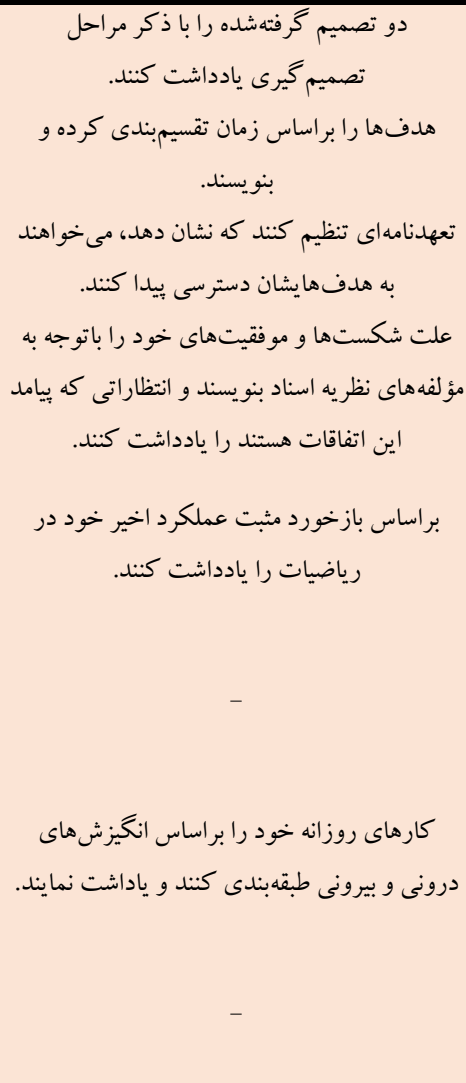 & 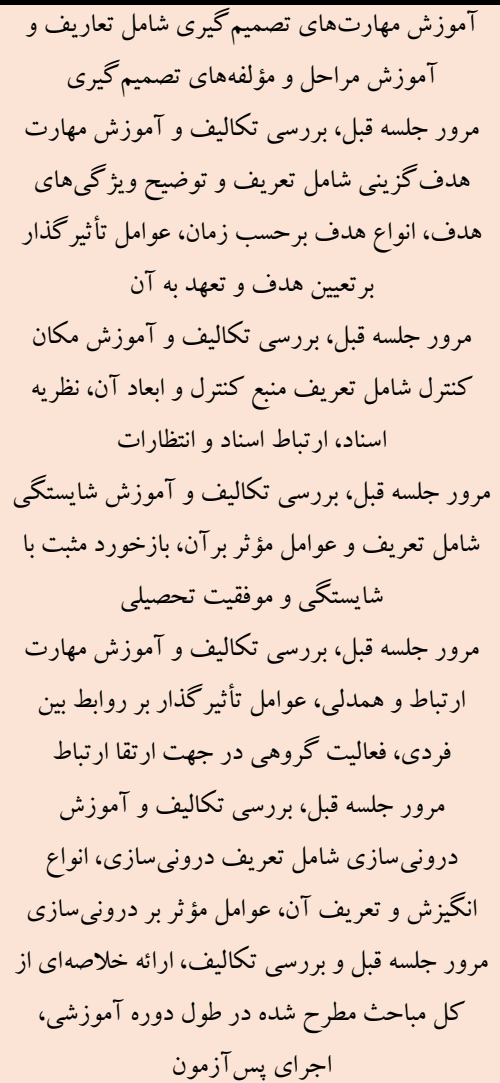 & 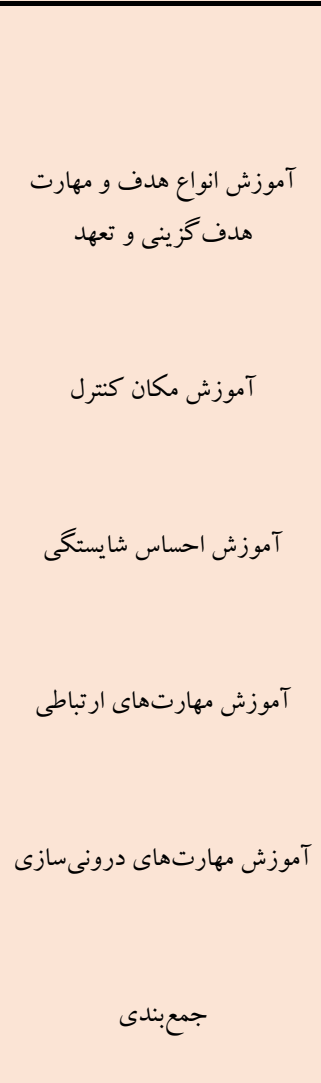 & 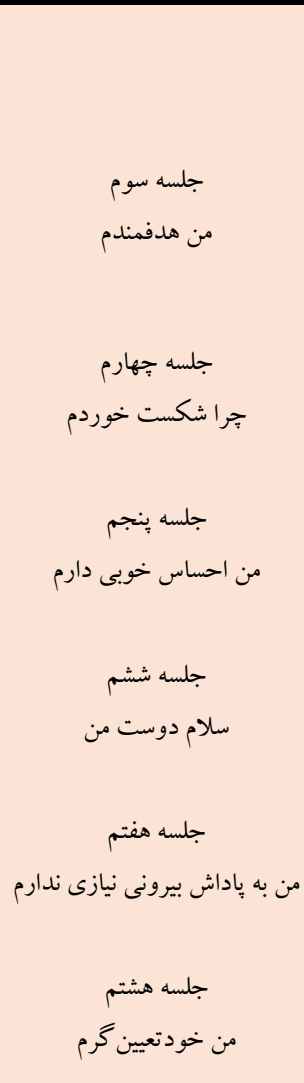 \\
\hline
\end{tabular}

ييش آزمون شده است. جولخى در تمامى متغيرها در دو گروه نشاندهنده

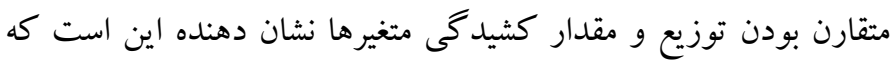
توزيع از كشيدگى نرمال برخوردار است.

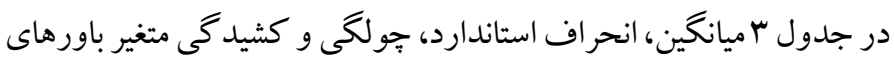

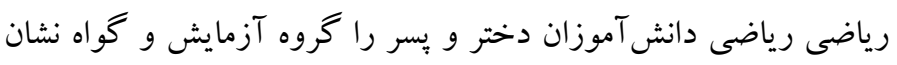

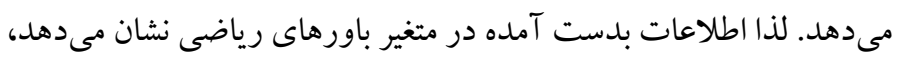

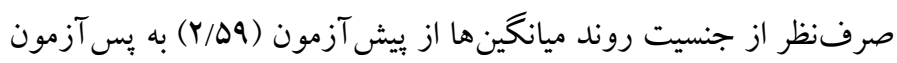

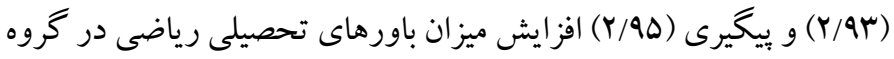

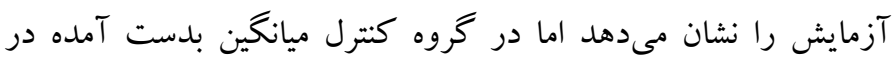

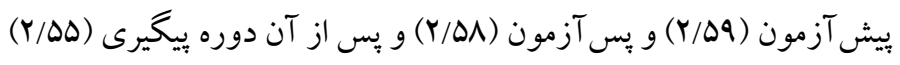

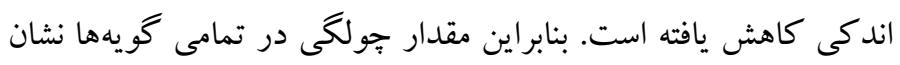

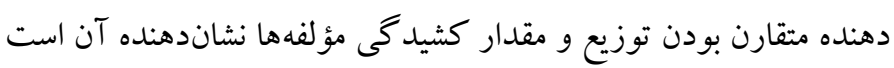

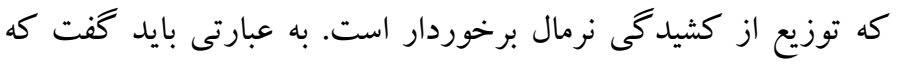

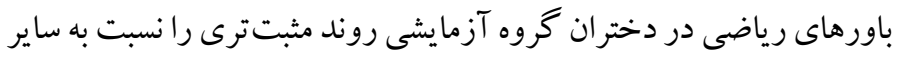
كروهها نشان مى دهد.
يافته ها براى تجزيه و تحليل دادهها در بخش آمار توصيفى از شاخصهاى مركزى

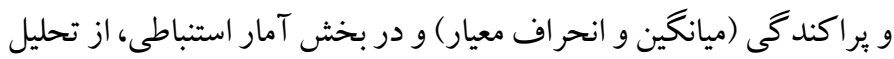

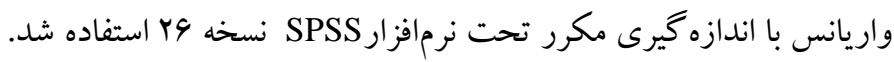
در اين بخش به ارائه يافتهاى توصيفى و استنباطى برداخته مي مشودر.

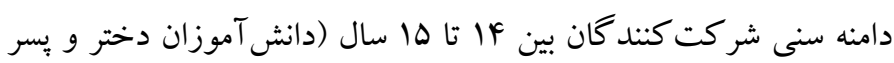

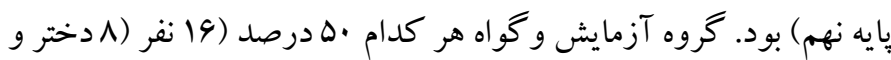

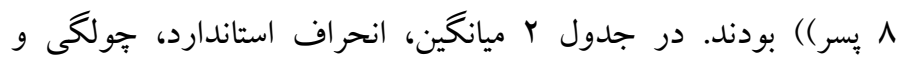

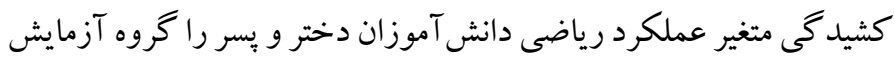

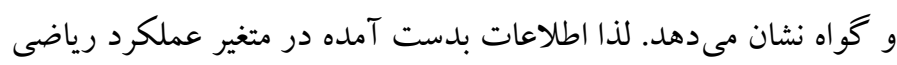
نشان مى دهد، صرفنظر از جنسيت روند ميانگين ها از بيش آزمون (V/ar)

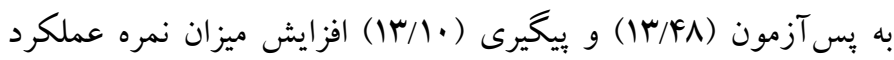
رياضى در گروه آزمايش را نشان مىدهد. در گروه كنترل ميانگين عملكرد

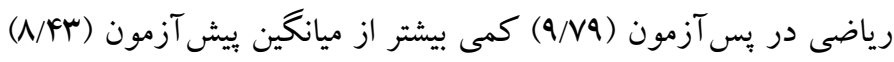

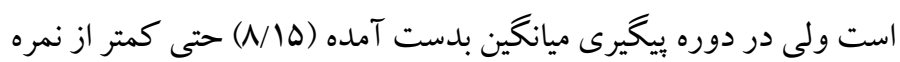




\begin{tabular}{|c|c|c|c|c|c|c|}
\hline كشيدگى & جولخى & انحر اف معيار & ميانگين & آزمون & & كروه \\
\hline$\cdot / \Delta V$ & $-1 / 1 r$ & I/Ar & N/ar & ي ييش آزمون & \multirow{3}{*}{ دختر } & \multirow{6}{*}{ زَمايش } \\
\hline$-\cdot / r V$ & $-\cdot / 4 q$ & $1 / 94$ & $|F / A|$ & يس آزمون & & \\
\hline$-1 / 94$ & $\cdot / \Delta \Delta$ & $1 / \Delta \wedge$ & $\mid F / \Delta q$ & يِيگيرى & & \\
\hline$-1 / 91$ & $-\cdot / \& V$ & $r / \cdot \Delta$ & $9 / 9$. & بيش آزمون & \multirow{3}{*}{ ل بسر } & \\
\hline-1 & $.19 \mathrm{~V}$ & $r / .9$ & $1 T / 10$ & يس آزمون & & \\
\hline $1 / 4 q$ &.$/ 90$ & $1 / v$ & $11 / 94$ & يِيخيرى & & \\
\hline$-1 / 1 V$ & $-\cdot / F r$ & $r / r$. & $\Lambda / Y \Delta$ & يِش آزمون & \multirow{3}{*}{ دختر } & \multirow{6}{*}{ كواه } \\
\hline . & $-\bullet / \wedge$. & $r / \cdot 1$ & $9 / 21$ & يس آزمون & & \\
\hline$-\cdot \cdot / \mu$ & $-\cdot / \wedge r$ & $r / \Delta$. & $\Lambda / \Delta$. & بيخيرى & & \\
\hline$-1 / 19$ & $-\cdot / \Delta r$ & $r / M$ & N/9Y & يِيش آزمون & \multirow{3}{*}{ يسر } & \\
\hline$-1 / \Gamma 4$ & $-\cdot / 49$ & $r / \mathcal{A V}$ & $Q / A V$ & پِ آزمون & & \\
\hline$-1 / 9 V$ & $-\cdot / 4 r$ & r/r & $\mathrm{V} / \mathrm{A} I$ & ييخيرى & & \\
\hline
\end{tabular}

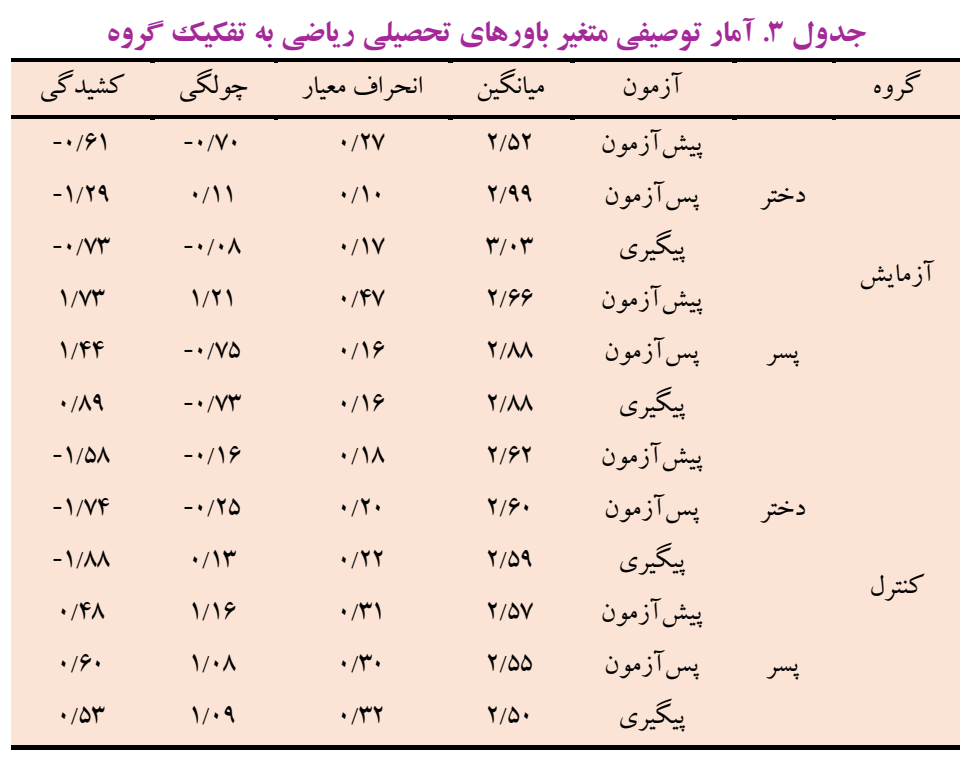

واريانس نمرات عملكرد و باور تحصيلى رياضى در دو گروه در مرحله

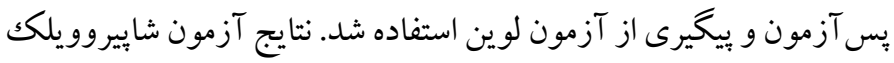

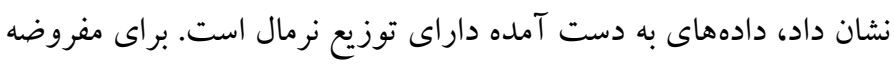

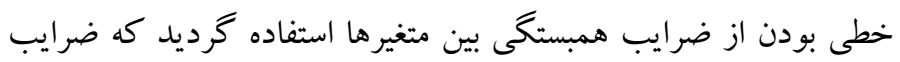

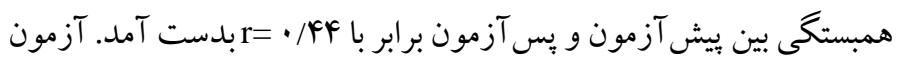
لوين جهت بررسى مفروضه همخنى واريانس هاى خطا استفاده شده است.

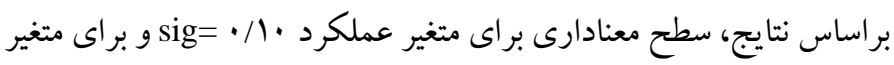

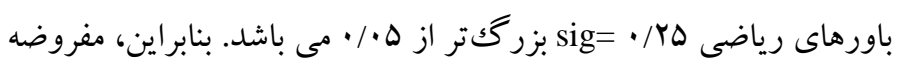

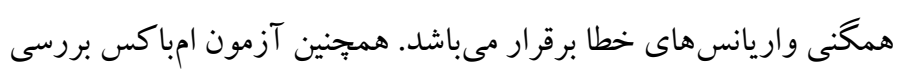

براى بررسى فرضيههاى تحقيق در ابتدا همبستخى بين متغيرهاى بيش آزمون

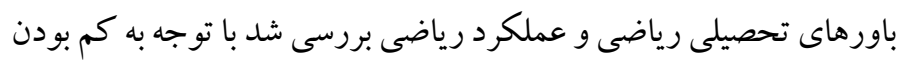

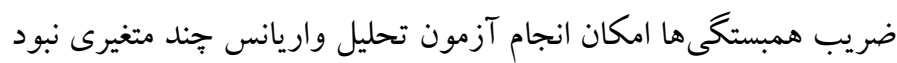
لذا از روش تحليل واريانس آميخته (يكك عامل درون گروهى و دو دو عامل

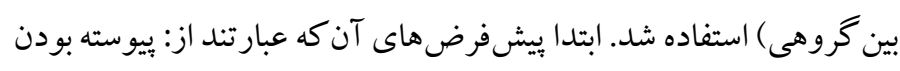

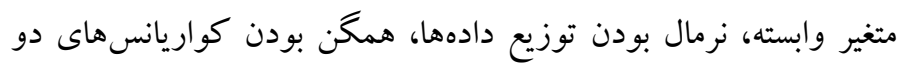

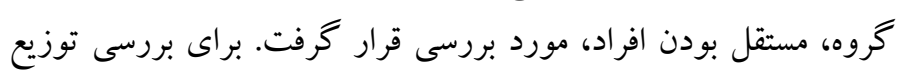

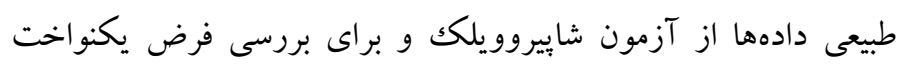

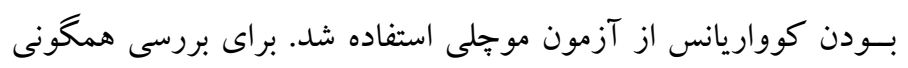




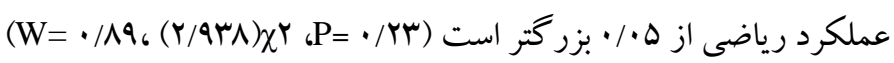
دادهها مفروضه همكنى كوواريانس ها را زير سؤال نبردهاند و اما براى متغير باورهاى رياضى با توجه به اينكه سطح معنادارى مقدار محاسبه شده

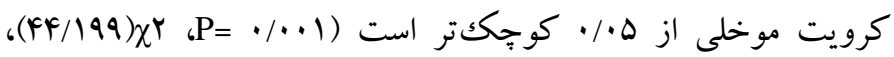
(W= • دادهها مفروضه همخنى كوواريانسها را زير سؤال بردهاند و بنابراين بايد براى اصلاح نقض فرضيات از تخمين ايسيلن يا آزمونهاى جندمتغيرى استفاده كرد. با توجه به حجم نمونه مناسب اين بثزوهش، بهترين مقدار إيسيلن، تخمين گرين هاوس -كيزر (Greenhouse-Geisser) است.
ماتريس هاى كوواريانس در دو گروه با سطح معنادارى بزرگكتر از I •/ تأييد شد. از آنجا كه اين مفروضات در دادهها برقرار بود لذا از آزمون تحليل واريانس با اندازه گيرى مكرر استفاده شد. در اين آزمون متغير جنسيت با دو سطح، متغير عملكرد و باور رياضى با سه سطح و گروه با دو سطح مورد بررسى قرار گرفتند. براى تحليل واريانس يك عاملى با تأكيد

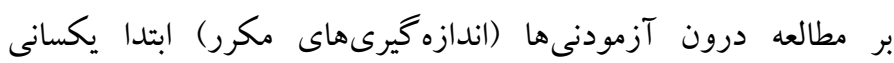
كوواريانسهاى متغير وابسته از طريق آزمون كرويت موخلى مورد بررسى قرار گرفت. خروجى اين آزمون در جدول ارائه F شده است. با توجه به موريه اينكه سطح معنادارى مقدار محاسبه شده كرويت موخلى براى متغير

جدول ع. نتايج آزمون كرويت موخلى در مورد همعَنى كوواريانسها

\begin{tabular}{|c|c|c|c|c|c|c|c|}
\hline Lower-bound & Huynh-Feldt & Greenhouse-Geisser & sig & df & خى دو & آزمون موخلى & تأثير درونى \\
\hline$\cdot / 0$ & 1 &.$/ 9$. & $\cdot / \pi r$ & r & r/QYA & $\cdot / 19$ & عملكرد رياضى \\
\hline$\cdot / 0$ & $\cdot / 94$ & $\cdot / \Delta \Delta$ &.$/ \cdot 1$ & r & $4 F / 199$ &.$/ 19$ & باورهاى رياضى \\
\hline
\end{tabular}

ساده و گروه (طرح r در r) با استفاده از آزمون تو كى باهم مقايسه شدند. در جدول 4 نتايج آزمون توكى يس از واقعه براى آزمون عملكرد رياضى با سه سطح ارائه شده است. در مورد آزمون عملكرد تحصيلى مقدار q با

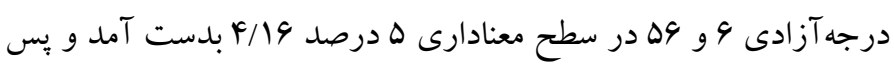
از آن مقدار توكى سو/1 محاسبه شد. ميانگين عملكرد رياضى پس آزمون گروه آزمايش با ميانگين عملكرد رياضى بيش آزمون اين گروه و بيش آزمون و يس آزمون و بيشيرى گروه كنترل تفاوت معنادار دارد ولى با ميانگين ييخيرى گروه آزمايش تفاوت معنادار ندارد. بنابر اين نتيجه مى توان كفت كه توانمند سازى در گروه آزمايش مؤثر بوده ولى با كذشت زمان اثرمداخله تقريبا ثابت مانده كه ميانگين بيكيرى گروه آزمايش در عملكرد تحصيلى نسبت به يس آزمون كمتر شده است. از سوى ديخر ميانكين بيكيرى كروه آزمايش با ميانكين هاى بيش آزمون، بس بس آزمون و ييخيرى گروه كنترل تفاوت معنادار داشته و با ميانگين بيش آزمون گرووه آزمايش نيز تفاوت معنادار دارد كه اين نشان دهنده اثر مداخله آزمايشى است. بنابراين فرضيه اول تحقيق در مورد تفاوت بين دو گروه آزمايش و كنترل تأييد مىشود ولى در مورد اثر تعاملى بين متغيرهاى جنسيت و عملكرد رياضى تأييد نشد.
در جدول ه خلاصه تحليل واريانس نمرات عملكرد رياضى ارائه شده است. خلاصه تحليل واريانس درون گروهى بيانخر آن است كه اثر تعاملى

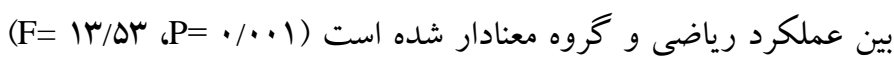
اين تعامل بيانكر اين است كه از تركيب سطوح عملكرد رياضى (ييش آزمون، يس آزمون و بيخيرى) و سطوح عامل گروه (كنترل و آزمايش) نتايج متفاوتى حاصل شده است. ولى اثر تعاملى بين عملكرد

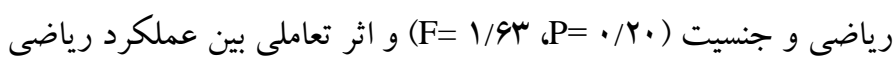

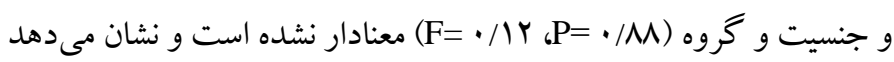
از تر كيب سطوح (ييش آزمون، يس آزمون و بيگيرى) عملكرد رياضى و سطوح عامل جنسيت (دختر و يسر) و سطوح عامل گرووه (كنترل و آزمايش) نتايج متفاوتى حاصل نمى شود. در تحليل واريانس بين كروهى با توجه به ميانگينهاى مشاهده شده مىتوان كفت تفاوت بين دو كروه

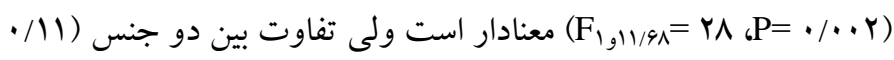

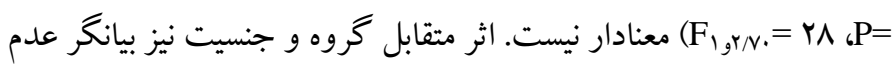
تفاوت معنادار در ميانگين جهار گروه در عاملهاى بررسى شده است

$$
\left(F_{1, r / \& q}=r \wedge{ }_{6} \mathrm{P}=\cdot / / r\right)
$$

با توجه به معنادار بودن اثر تعاملى گروه و آزمون، براى بررسى معنادار بودن تفاوت ميانگينهاى بيش آزمون، بس آزمون و بيگيرى ميانگين هاى اثرهاى 
جدول ه. نتايج تحليل واريانس درون گروهى و بين گروهى (عملكرد رياضى)

\begin{tabular}{|c|c|c|c|c|c|c|}
\hline Sig & $\mathrm{F}$ & MS & $\mathrm{DF}$ & SS & منابع متغيير & \\
\hline.$/ \cdots 1$ & Ar/lar & $1.1 / \pi 90$ & r & $r \cdot r / V q$ & عملكرد رياضى (آزمون رياضى) & \multirow{4}{*}{ ترون گروهى } \\
\hline$\cdot / r$ & $1 / 94$ & $r / \cdot 1$ & r & $r / \cdot r$ & عملكرد رياضى ** جنسيت & \\
\hline.$/ .1$ & $\Delta r / I r$ & $90 / 09$ & r & $\mid r / M r$ & عملكرد رياضى ** گروه & \\
\hline$\cdot / M$ & $\cdot / r$ &.$/ 10$ & r & $\cdot r$ & عملكرد رياضى ** جنسيت * كروه & \\
\hline- & - & $1 / r$ & $\Delta 4$ & $99 / 1$. & خطا & \multirow{5}{*}{ بين گروهى } \\
\hline.$/ 11$ & $r / v \cdot$ & $4 \cdot 199$ & 1 & $f \cdot 199$ & جنسيت & \\
\hline / Hr & $11 / 9 \Lambda$ & $|V q| \cdot F$ & 1 & $|V q| \cdot F$ & كروه & \\
\hline$\cdot / 1 r$ & $r / \& q$ & $r V / \Delta$. & 1 & $r V / \Delta$. & جنسيت گروه & \\
\hline- & - & $10 / \cdot 9$ & ru & FYI/V. & خطا & \\
\hline
\end{tabular}

جدول ح. نتايج آزمون توكى پّ از واقعه براى آزمون عملكرد رياضى با سه سطح

\begin{tabular}{|c|c|c|c|c|c|c|}
\hline بس آزمون آزمايش & بيخيرى آزمايش & پِ آزمون كنترل & بيش آزمون كنترل & بيخيرى كنترل & يِش آزمون آزمايش & نام گروه \\
\hline $\mid r / 4 \Lambda$ & $\mid r / 1$. & $9 / \mathrm{Q}$ & $N / F r$ & $1 / 10$ & V/ar & ميانگين \\
\hline$\Delta / \Delta Q$ & $\Delta / 1 \Lambda$ & I/AV & $\cdot / \Delta 1$ & r & . & $V / a Y$ \\
\hline & $F / 90$ & $1 / 94$ & $\cdot / Y \wedge$ & . & - & $1 / 10$ \\
\hline$\Delta / \cdot \Delta$ & $F / 9 \mathrm{~V}$ & $1 / 49$ & . & - & - & $\Lambda / A \mu$ \\
\hline$r / 99$ & $r / r$ & . & - & - & - & १/VQ \\
\hline$\cdot / \mu \Lambda$ & . & - & - & - & - & $\mid r / 1$. \\
\hline . & - & - & - & - & - & $|r / 4 \lambda|$ \\
\hline
\end{tabular}

$$
.\left(F_{1, * r}=r \wedge \text { } \mathrm{P}=\cdot / \wedge 9\right)
$$

با توجه به معنادار بودن اثر تعاملى گروه و آزمون در ميانگين باورهاى

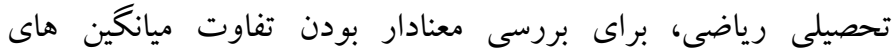

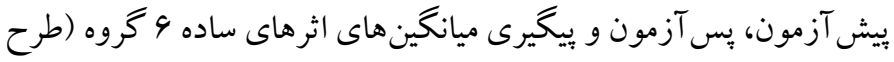

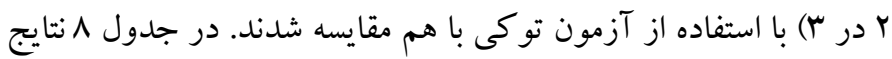

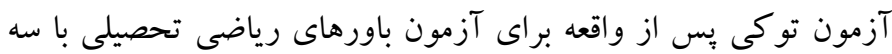
سطح ارائه شده است. در مورد آزمون باورهاى رياضى مقدار q با درجه

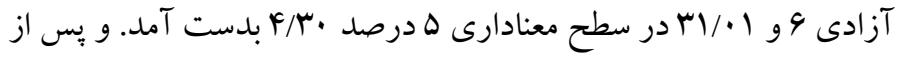
آن مقدار توكى Y./ محاسبه شد. نتايج تفاوتهاى محاسبه شده بين

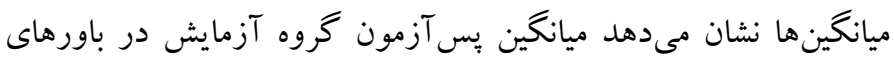

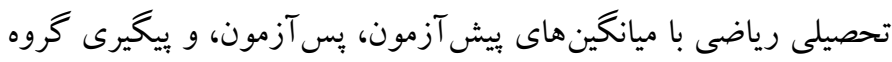

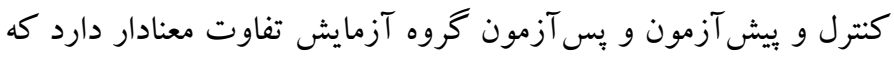

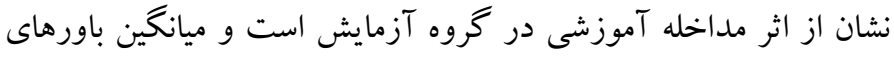

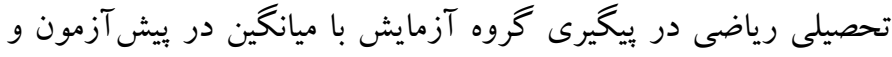

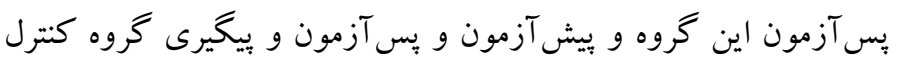

در جدول Vحلاصه تحليل واريانس نمرات باور رياضى ارائه شده است.

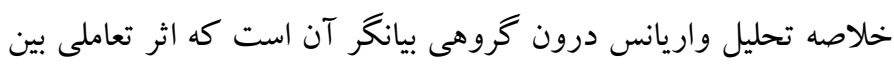

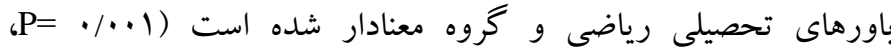

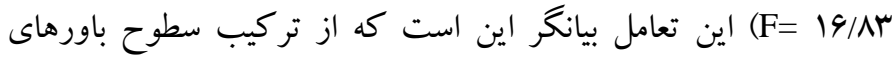

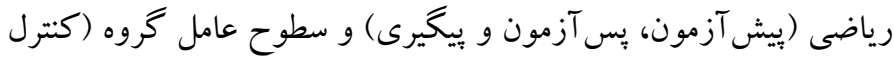
و آزمايش) نتايج متفاوتى حاصل شده است. ولى اثر تعاملى بين باورهاى

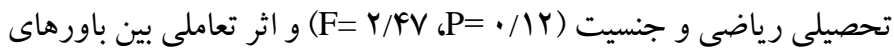

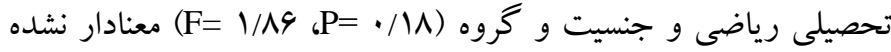
است و نشان مى دهد از تركيب سطوح (ييش آزمون، يس آزمون و يِيخيرى) و سطوح عامل جنسيت (دختر و بّر) و سطوح عامل گروه (كنترل و و

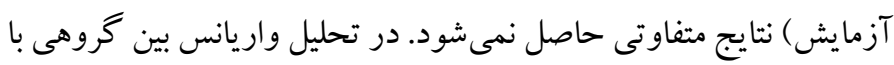

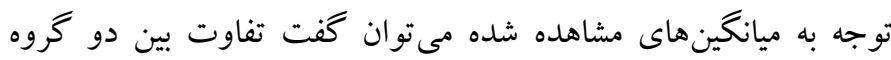

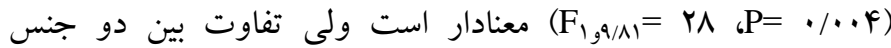

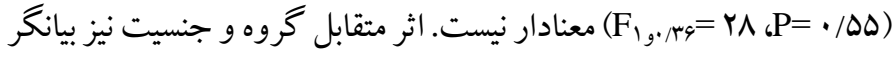

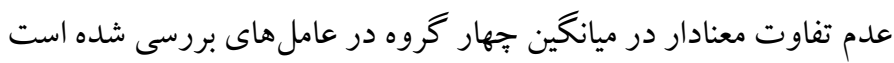


بوده و رشدى نداشته است. بنابراين فرضيه دوم تحقيق تنها در مورد تفاوت

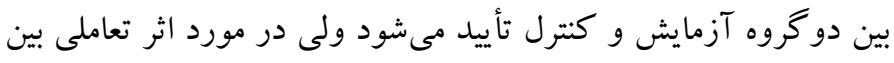
متغيرهاى جنسيت و باورهاى تحصيلى رياضى تأييد نشد.
تفاوت معنادار دارد بنابر اين مى توان نتيجه گرفت مداخله آموزشى در گروه آزمايش هم در يس آزمون اثر بخش بوده و هم در دوره يِيخيرى توانسته

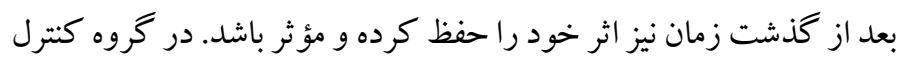

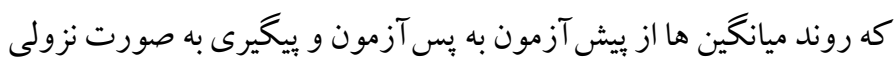

جدول Y. تتايج تحليل واريانس درون كروهى و بين كروهى (باور رياضى)

\begin{tabular}{|c|c|c|c|c|c|c|}
\hline Sig & $\mathrm{F}$ & MS & $\mathrm{DF}$ & SS & منابع متغيير & \\
\hline$\% 1$ & $11 / 99$ & $\cdot / 0$ & $1 / 1$ & $\cdot / \Delta \Delta$ & باورهاى رياضى (آزمون رياضى) & \multirow{4}{*}{ درون گروهى } \\
\hline$\cdot / l r$ & $r / F V$ & $\cdot /$ & $1 / 1$. &.$/ 11$ & باورهاى رياضى ** جنسيت & \\
\hline.$\cdot \cdot 1$ & le/Ar & $\cdot / V r$ & $1 / 1$ & $\cdot / \wedge$ & باورهاى رياضى ** گروه & \\
\hline$\cdot / 1 \Lambda$ & $1 / \wedge 9$ & $\cdot / \cdot \wedge$ & $1 / 1$ & $\cdot / \cdot \wedge$ & باورهاى رياضى * جنسيت * گروه & \\
\hline- & - & $\cdot / \cdot r$ & $\mathrm{~m} / \cdot 1$ & 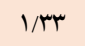 & خطا & \multirow{5}{*}{ بين خروهى } \\
\hline$\cdot / \Delta \Delta$ & . &.$/ .0$ & 1 & $\cdot / \cdot \Delta$ & جنسيت & \\
\hline$\%$ & $9 / \wedge 1$ & $1 / \Delta 9$ & 1 & $1 / \Delta 9$ & كروه & \\
\hline$\cdot / \wedge 9$ & $\cdot / \cdot r$ & $\cdot / \cdot r$ & 1 & 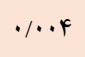 & جنسيت & \\
\hline- & - &.$/ 10$ & rی & $F / 49$ & خطا & \\
\hline
\end{tabular}

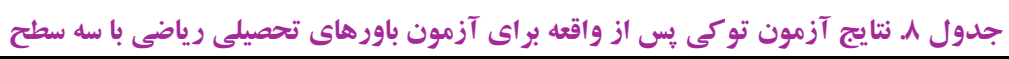

\begin{tabular}{|c|c|c|c|c|c|c|}
\hline بيشيرى آزمايش & پِ آزمون آزمايش & يِش آزمون آزمايش & ييش آزمون كنترل & پس آزمون كنترل & يبيخيرى كنترل & نام گروه \\
\hline$r / 90$ & r/৭r & $r / \Delta Q$ & $r / \Delta 9$ & $r / \Delta \Lambda$ & $r / \Delta \Delta$ & ميانخين \\
\hline$\cdot / 4$. & $\cdot /$ / &.$/ . F$ & $\%$ & $\cdot / \cdot r$ & . & $r / \Delta \Delta$ \\
\hline$\cdot / M V$ & . &.$/ \cdot 1$ &.$/ \cdot 1$ & . & - & $r / \Delta \Lambda$ \\
\hline . & $\cdot / \mu F$ & . & . & - & - & $r / \Delta Q$ \\
\hline$\cdot / 49$ & $\cdot / \mu F$ & . & - & - & - & $r / \Delta Q$ \\
\hline.$/ \cdot r$ & · & - & - & - & - & $r / 9 T$ \\
\hline · & - & - & - & - & - & $r / 90$ \\
\hline
\end{tabular}

نتايج به دست آمده از اين تحقيق همسو با نتايج تحقيقات، يزوهش لئون،

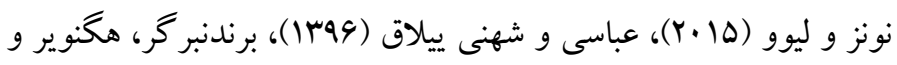

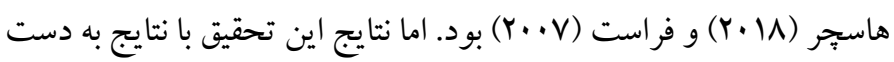

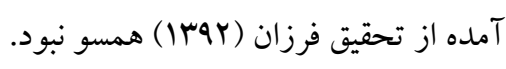

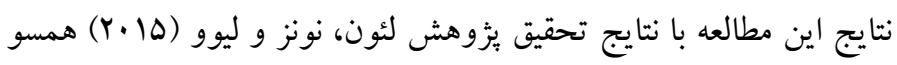

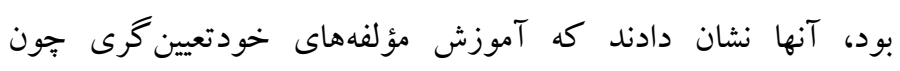
خودمختارى، انخيزش و خود تنظيمى بر بيشرفت رياضى دانش آموزان مؤثر

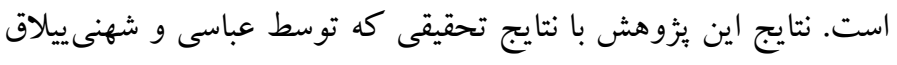

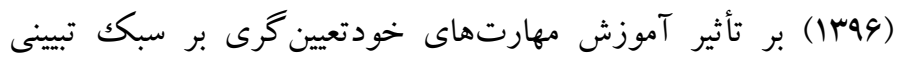

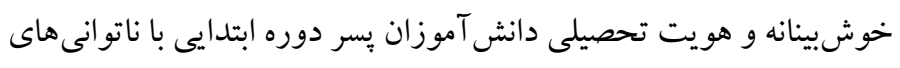

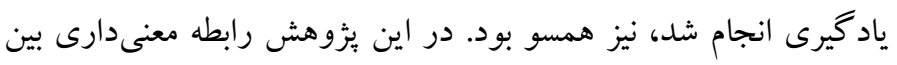

بحث و نتيجه تيرى يُزوهش حاضر با هدف تدوين و طراحى بسته آموزشى توانمندسازى با

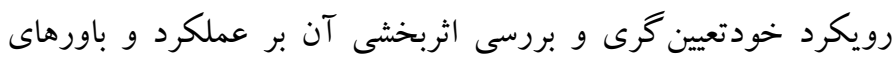

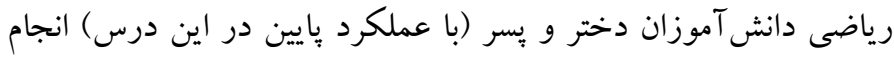

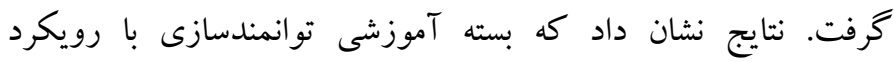

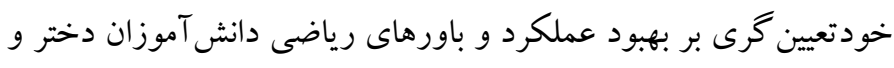

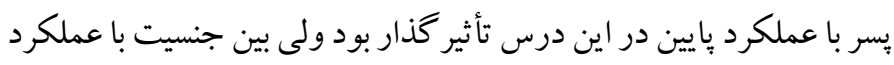

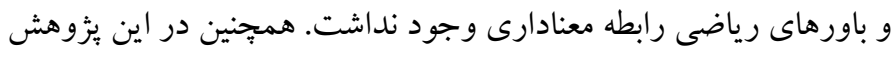

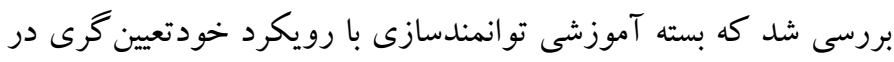

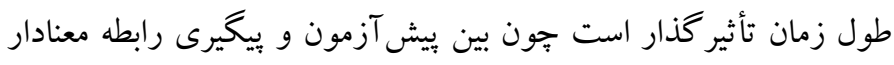
وجود داشت. 


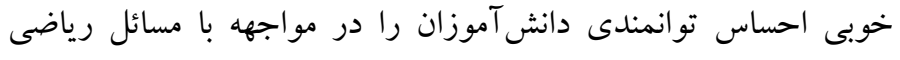

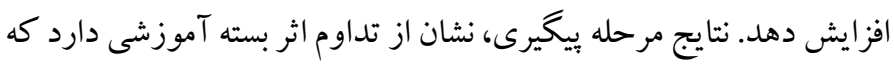

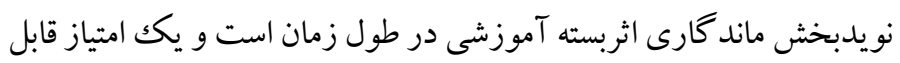

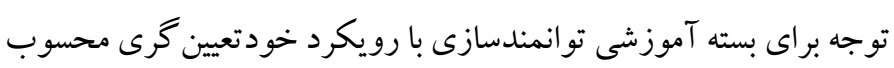

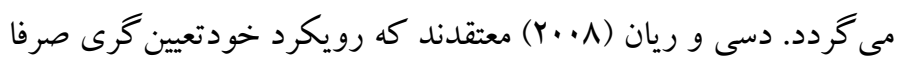
يكك شيوه تفكر نيست، بلكه يكك سبك (جهت گيرى زند

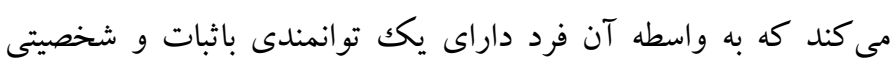

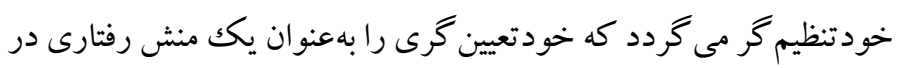
برخورد با مسائل روزمره بهصورت خود كار تجربه و احساس مى مكند.

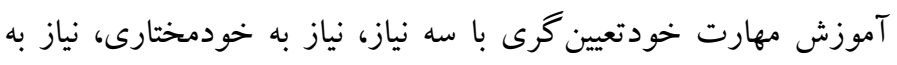

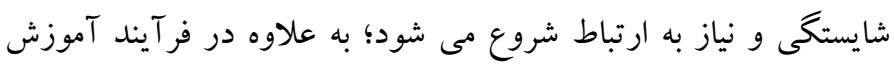

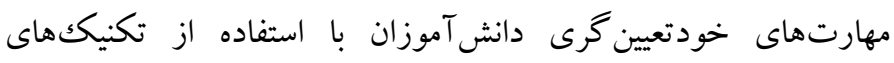

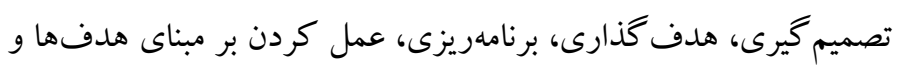

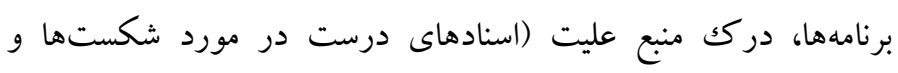

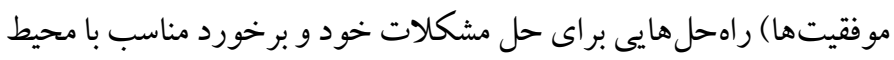
به ويزه در برخورد با مسائل درسى (رياضى) خلق مى كنند.

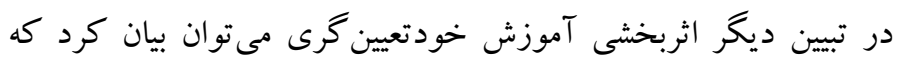

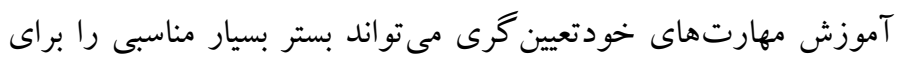

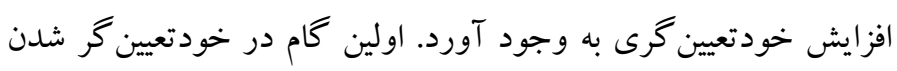
شناخت بيشتر از توانايىها و محدوديت هاى خويش است (فيلد و هافمن،

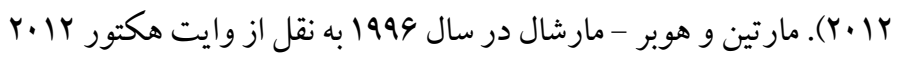

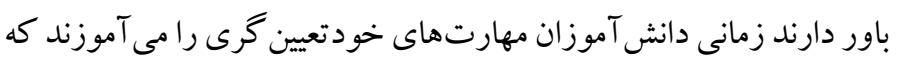

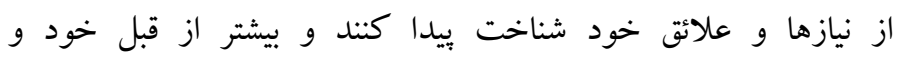

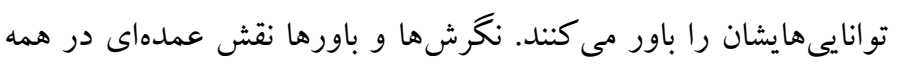

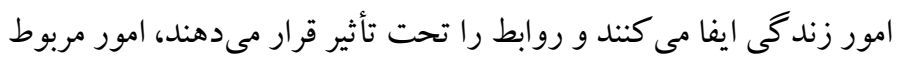

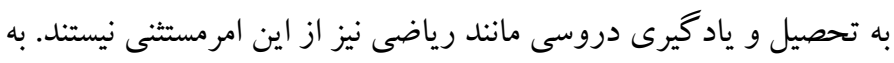

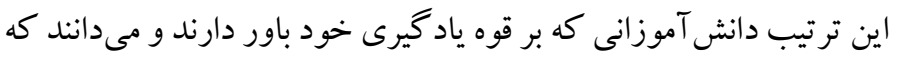

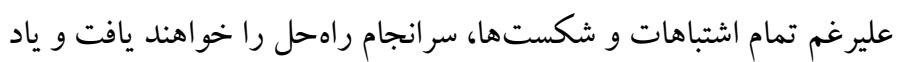

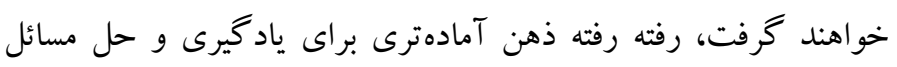

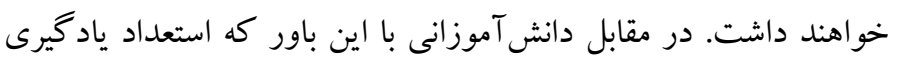

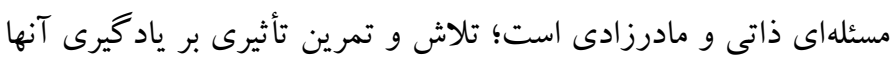

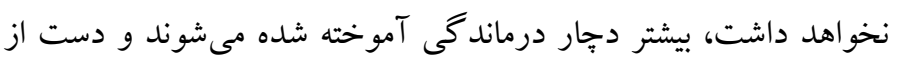

آموزش مهارتهاى خودتعيين گرى با سبك تبينى خوشبينانه و هويت

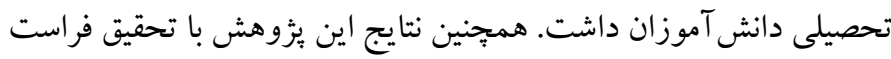

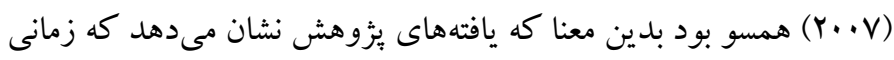

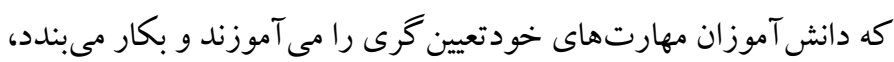
موفقيت بيشترى در تحصيل ييدا مى كنند. نتايج اين يزوهش بـ با نتايج تحقيقى

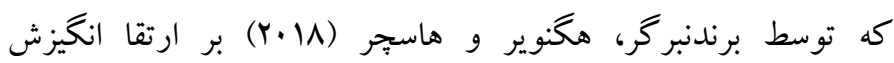

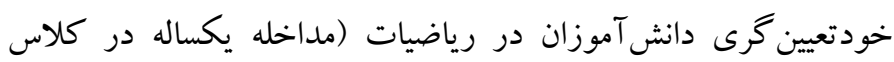

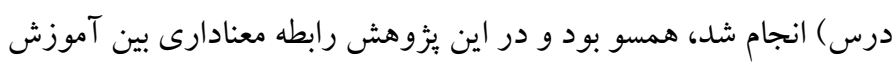
خودتعيين گرى و ييشرفت رياضى وجود داشت.

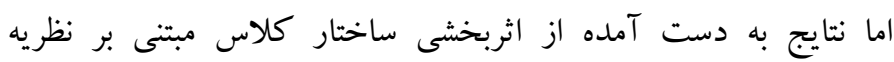

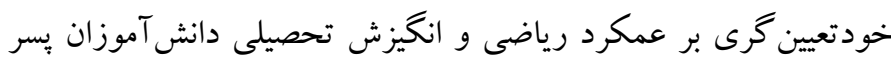

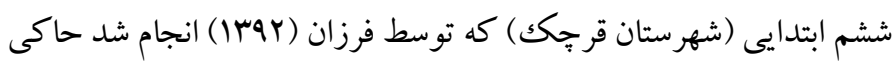

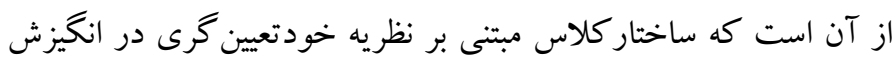

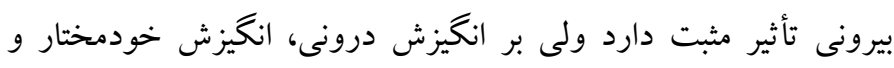

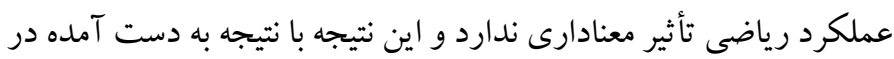

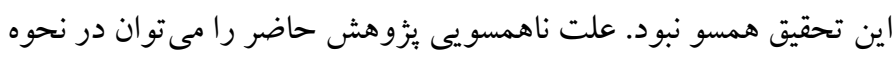

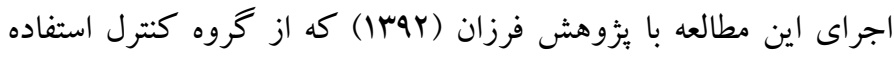

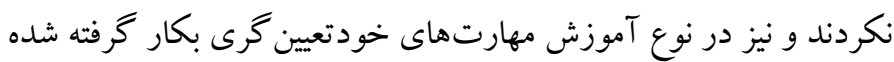

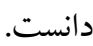

با توجه به نتايج به دست آمده از بثزوهش به همراه توضيحاتى كه ارائه شد در مجموع مى توان نتيجه گرفت كه آموزش بسته توانمندسازى با رويكرد

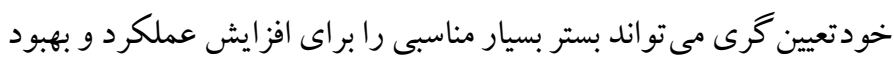

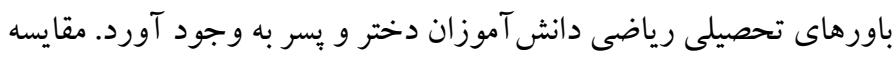

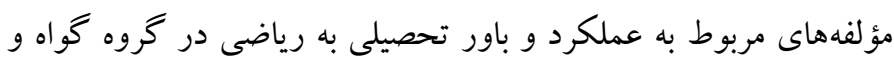

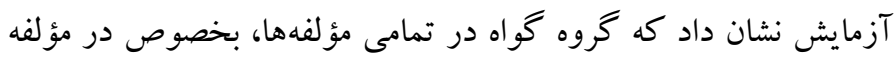

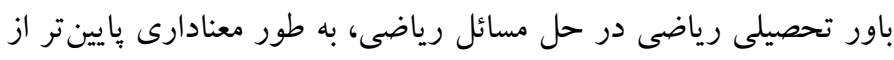
گروه آزمايش است. احساس توانمندى يا به تعبيرى خودباورىى، به به تعبير

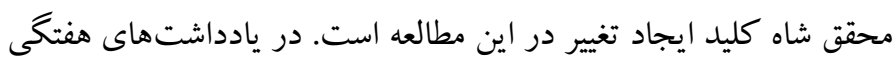

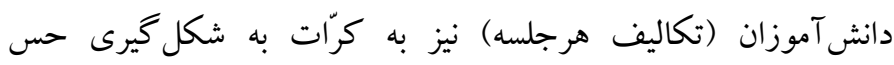

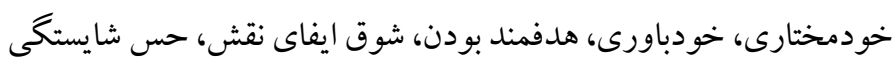

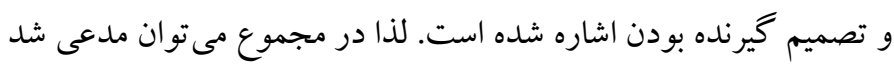

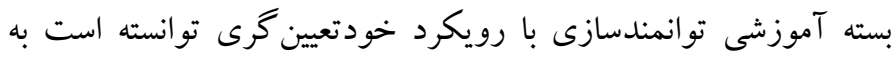


مخصوصا در زمينه بسته آموزشى توانمندسازى با رويكرد خودتعيين گرى و باورهاى تحصيلى رياضى بسيار كم بود و اين موضوع بيشينه يثوهش را ضعيف كرد. بر اساس محدوديت هاى اين بزوهش نظير محدود بودن نتايج يثزوهش به كرووه و منطقه جغر افيايى خاص (دانش آموزان دختر و بِر يايه نهم منطقه ششم آموزش و برورش شهر تهران) بيشنهاد مىشود كه نظير اين يثزوهش در جامعه آمارى ديخر و ساير مناطق جغر افيايى انجام كردد تا سبب افزايش تعميم يافتها شود. با توجه به يافتههاى حاصل از يزوهش حاضر توصيه مى گردد بسته آموزشى تو انمندسازى با رويكرد خود تعيين گرى در نهادهاى تعليم و تربيتى وابسته به آموزش و يرورش مورد استفاده قرار كيرد.

\section{ملاحضات اخلاقى}

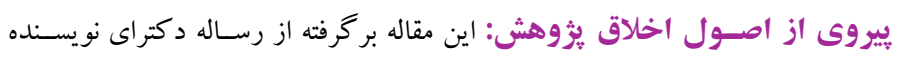
نخست در رشته روانشناسى تربيتى دانشگاه آزاد اسلامى واحد علوم و تحقيقات و تاريخ

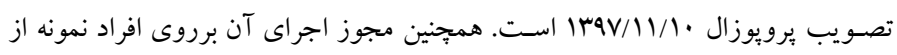

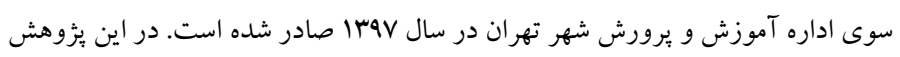
ملاحضـات اخلاقى مانند رضـايت كامل افراد نمونه، رعايت اصـل رازدارى و محرمانه

$$
\text { ماندن اطلاعات رعايت شده است. ملاتح مضان }
$$

حامى مالى: اين مطالعه بدون حامى مالى و در قالب رساله دكترا انجام شدهاست. نقش هر يكك از نويسند

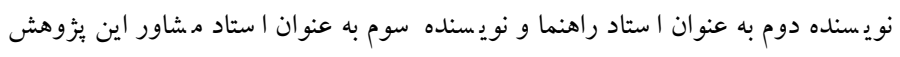
نقش داشتند.

تضاد منافع: اين يزوهش براى نويسند گان هيج گُونه تضاد منافعى نداشتهاست. تشكر و قدردانى: بدين و سيله از استادان راهنما و مشاور اين مطالعه، همكارى بسيار خوب افراد نمونه، مسئولان اداره آموزش و يرورش منطقه شش شهر تهران و كادر ادارى و مشاوران مدارس، تشكر و قدردانى مىشود.
تلاش براى يادگيرى بر مىدارند. بدين رو با آموزش بسته توانمندسازى با

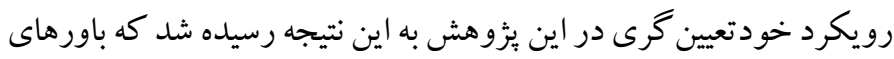

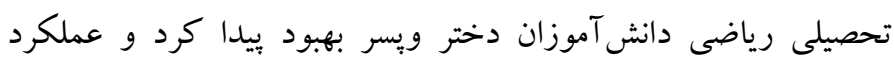
بالاترى در رياضى از خود نشان دادند.

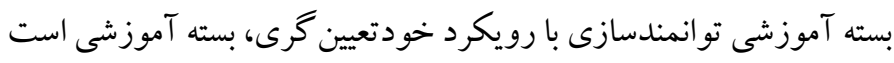
كه به جنبههاى خود كار آمدى فرد و تو انمندسازى او تكيه دارد و از آنها تورديا حمايت مى كند. بسته آموزشى توانمندسازى با رويكرد خودتعيين گرى جرى

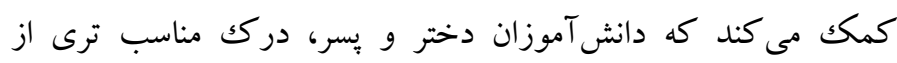

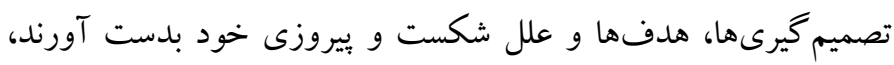

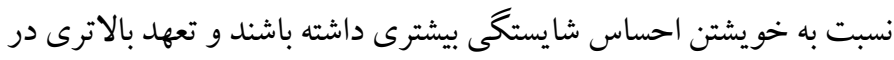

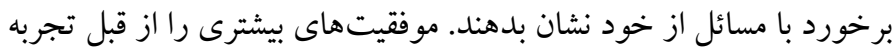

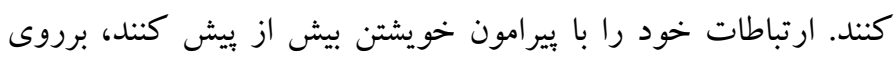

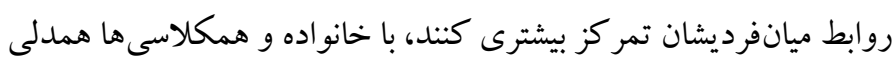

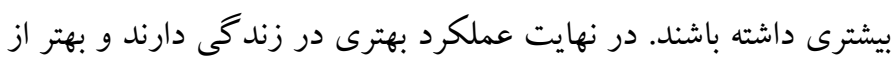
قبل خود وتوانايىهاى خويشتن را مىشناسند و بر آنها يقين و باور بيدا

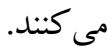
براى انجام اين يُروهش محقق با محدوديتهايى روبرو بود از جمله: براى

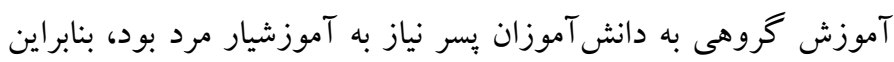

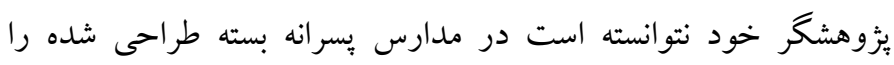

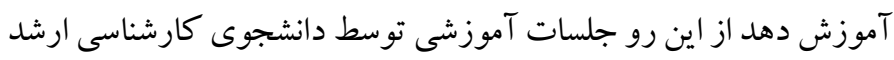

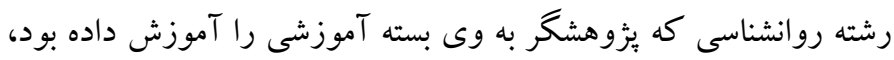

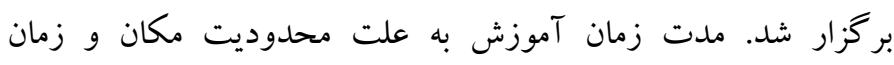

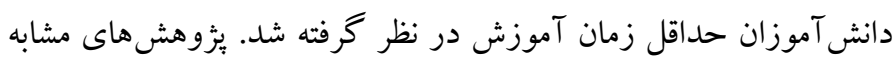




\section{References}

Abbasi, Mohammad and Shahni Yilagh, Manijeh. (2017). The effect of self-determination skills training on optimistic explanatory style and academic identity of male primary school students with learning disabilities. Psychiatric Nursing, 5 (5), 1-7. [Persion] [Link]

Alizadeh Gorji, The Sun. (2010). Relationship between academic failure and school mathematics decline. 11th Iranian Mathematics Education Conference, Sari. [Persion] [Link]

Baffour, Tiffany. D, Chonody. Jill M, (2012). Do Empowerment Strategies Facilitate Knowledge and Behavioral Change? The Impact of Family Health Advocacy on Health Outcomes, Journal of Social Work in Public Health, 27 : 507-519. [Link]

Bryant, B. R. Bryant, D. P. \& Porterfield,J. (2014). The Effects of a Tier 3 Intervention On the Mathematics Performance of SecondGrade Students with Severe Mathematics Difficulties. Journal of Learning Disabilities. [Link]

Boaler, J. , Williams, C. and Munson, J. (2018). Mindset Mathematics : Visualizing and Investigating Big Ideas, Grade 3. ISBN: 978-1-119-35870-1 JOSSEY - BASS . [Link]

Brandell, G., Leder, G. and Nystrom, P. (2017). Gender and Mathematics: Recent development from a Swedish perspective. ZDM, 235-250. [Link]

Brandenberger, C., Hagenauer, G. and Hascher, T. (2018) . Promoting students' self-determined motivation in maths: results of a 1-year classroom intervention . European Journal of Psychology of Education ., 295- 317. [Link]

Charmchian Langroudi, Mehdi and Ali Beigi, Amir Hossein. (2013). Investigating the effective factors on psychological empowerment of rural women. Women and Society, 4 (1), 165-192.[Persion] [Link]

Deci, E. L., \& Ryan, R. M. (2008). Self-Determination Theory: A Macrotheory of Human Motivation, Canadian Psychology, 49(3), 182-185. [Link]

Ebrahim Kafouri, Kimia; Maleki, Hassan and Khosrobabadi, Ali Akbar. (2014). Investigating the role of Klein curriculum elements in the academic failure of the first year of high school mathematics from the perspective of curriculum partners. Curriculum Research, 2 (17), 50-62.[Persion] [Link]

Farzan, Ali (2013). The effectiveness of class structure based on self-determination theory on mathematical performance and academic motivation of sixth grade male students (Qarchak city). Thesis for obtaining a master's degree in educational psychology. University of Tehran: Tehran. .[Persion] [Link]

Fereydoni, Somayeh and Mehran, Golnar. (2012). A New Understanding of the Concept of Women's Empowerment: Elements and Processes. cultural management. 6 (17), 71-88.[Persion] [Link]

Field, S., \& Hoffman, A. (2012). Development of a model for self-determination.Career Development for Exceptional Individuals, 17, 159-169. [Link]

Faramarzpour, Noushin and Rafi. Poor, Abolfazl (2014). Math-related gender beliefs in students' minds. Iranian Curriculum Studies, 9 (34), 132-117. [Persion] [Link]

Faramarzpour, Nooshin; Rafipour, Abolfazl and Hossein Chari, Massoud. (2015). Investigating the psychometric properties of the Mathematical Academic Beliefs Scale. Educational Measurement, 6 (19), 173-188.[Persion] [Link]

Frost,Sh. (2007). Ways to increase self- determination skills in students. American Psychology Association . 45 (3) . 134-145. [Link]

Geary, D. (2004). Mathematics and Learning Disabilities. Journal of Learning Disabilities; 37(1):4-15. [Link] Ghasemi, Maryam; Alizadeh, Lida and Kandahari, Elham. (2018). Develop psychological empowerment strategies for rural women using strategic management tools. Women in Development and Politics, 16 (1), 79-109. [Persion] [Link]

Gholipour, Arian; Rahimian, Ashraf and Mirzamani, Azam. (2008). The role of formal education and organizational employment in empowering women in Tehran. Women's Research, 6 (3), 113-132. [Persion][Link]

Haji Hosseinlou, Khadijeh; Creator, Ali; Zahed Babalan, Adel and Moeini Kia, Mehdi. (2017). The effect of collaborative learning with progress groups on students' self-efficacy and math self-concept. Educational Psychology, 13 (43), 117-137. [Persion] [Link]

Jalili, Farokhro; Arefi, Mojgan; Qamrani, Amir and Munshii, Gholamreza. (2019). The effectiveness of self-determination training on academic motivation and fascination of students and teachers of Farhangian University of Birjand. Journal of Educational Psychology Studies. 34, 27-53. [Persion] [Link]

Janaabadi, Hussein; Burghaz, Abdul Wahab and Shabani, Mahtab. (2017). A comparative study of the relationship between the basic psychological needs 
of self-determination and individual adjustment in gifted and normal students. School Psychology, 3 (6), 25 - 45. [Persion] [Link]

Kharazmi, Ahmad; Karshki, Hossein and Abdokhodaei, Mohammad. (2012). The role of basic needs of selfdetermination, information quality and applicability in the interest in continuing e-learning through mediation of internal motivation and satisfaction. Teaching and Learning Studies, 4 (2), 2-20. [Persion] [Link]

Leon, J. , Nunez, J.L. \& Liew, J. (2015) . Selfdetermination and STEM education:Effects of autonomy, motivation and self-regulated learning on high school math achievement . learning and individual differences , 43 , 156- 163 . [Link]

Lerch, C. M. (2018). Control decisions and personal beliefs: Their effect on solving mathematical problems. Journal of Mathematical Behavior, 23, 21-36. [Link]

Nawaz, Q., Hussain, L., Abbas, A., \& Javed, M. (2014). Effect of cooperative learning on the academic and self concept of the students at elementary school level. Gomal University Journal of Research, 30(1): 127-135. [Link]

Nguyen, G. and Goodin, Joel,B. (2016) . Bringing Students Back to Mathematics: Classroom Knowledge and Motivation . Journal of Humanistic Mathematics . 6 , 46-83. [Link]

Niemiec, C.P., Ryan, R.M., and Deci, E.L. (2009). The path taken: consequences of attaining intrinsic and extrinsic aspirations in post- college life. Journal of research in personality, 201-306. [Link]

Parhizgar, Zakia; Alam al-Hedai, Hassan and Jabbari Noghabi Mehdi. (2017). The capacity to teach modeling problems to change students' attitudes toward mathematics. Theory and Practice in the Curriculum, 5 (9), 167 - 192.[Persion] [Link]

Pishgahi Fard, Zahra; Zohdi Goharpour, Mohammad and Abedini Rad, Arezoo. (2014). Gender Empowerment Functions in Developing Women's Political Participation Case Study: Central Asian and Caucasus Countries. Central Ursia Studies. 2 (7), 265-289.[Persion] [Link]

Rastegar, Ahmad; Ghorban Jahromi, Reza, Gholam Ali Lavasani; Massoud and Nikbakht, Maryam. (2015). Relationship between epistemological beliefs and mathematical academic achievement: the mediating role of achievement goals, mathematical selfefficacy and cognitive engagement. Fourth National Conference and Third International Conference on Skills, Training and Employment, Tehran,
Technical and Vocational Education Organization. [Persion] [Link]

Sol Ibarra-Rovillard. M. and Kuiper, N. A. (2011). Social support and social negativity findings in depression: Perceived responsiveness to basic psychological needs .Clinical Psychology Review, 342-352. [Link]

Swaina, Ranjula Bali. (2012). Factors empowering women in Indian self-help group programs, Journal of International Review of Applied Economics, 26, 4, : 425-444. [Link]

Taghizadeh, Roghayeh and Abdoli Sultan Ahmadi, Javad. (2017). The Effectiveness of Jigsaw Teaching Method on Mathematical Self-Efficacy and Mathematical Anxiety in Statistics and Modeling among Secondary School Humanities Students. School Psychology, 2 (6), 7-25.[Persion] [Link]

Vahedi, Shahram; Farjian, Fatemeh and Hatami, Javad. (2017). Analysis of motivational profile and academic achievement of students in mathematics based on the perspective of self-determination. Journal of Educational Psychology, 13 (45), 97119.[Prsion] [Link]

White-Hector, A. (2016). The effectiveness of the choice maker curriculum in increasing self-determination skills in high school special education students.Unpublished doctoral dissertation, University of Walden, Minnesota. [Link]

Yarmohammadi, Mosayeb; Maqami, Hamid Reza (2010). Investigating the factors affecting the academic failure of high school mathematics (Sardrood region). Journal of Educational Sciences, Shahid Chamran University of Ahvaz, 2 (19), 122.[Persion] [Link]

zeraati Idealoo, Roghayeh; Zargham Hajebi, Majid and Kamkari, Kambiz (2020). Comparison of the effectiveness of the third level of response to intervention and cognitive empowerment on students' math performance with math disorder. Learning Disabilities, 9 (3), 68-93.[Persion] [Link] 